GEOLOGICAL SURVEY CIRCULAR 346

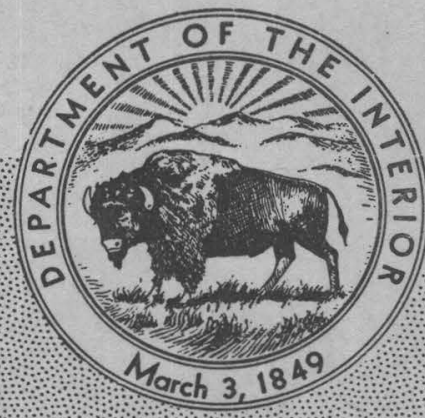

FIRST FOURTEEN YEARS

OF LAKE MEAD

Based on the report of the Lake Mead Comprehensive Survey of 1948-49 

UNITED STATES DEPARTMENT OF THE INTERIOR

Douglas McKay, Secretary

GEOLOGICAL SURVEY

W. E. Wrather, Director

GEOLOGICAL SURVEY CIRCULAR 346

\title{
FIRST FOURTEEN YEARS OF LAKE MEAD
}

\author{
By Harold E. Thomas
}

Based on the report of the Lake Mead Comprehensive Survey of 1948-49 


\section{PREFACE}

An intensive investigation of Lake Mead, the reservoir formed by Hoover Dam on the Colorado River, was begun in January 1948 and completed late in 1950. The investigation was conducted under the general direction of a project staff composed of representatives of the three principal participating agencies: William O. Smith, Geological Survey; Carl P. Vetter, Bureau of Reclamation; and George B. Cummings, Bureau of Ships, Navy Department. The technical report on this investigation, which is being prepared by the Geological Survey, presents the analytical data and conclusions in detail. An advance draft was reproduced by the Bureau of Reclamation for official use and review by the cooperating agencies and others concerned.

The comprehensive survey of Lake Mead required the talents of a diverse group of specialists and effective coordination of their individual efforts. These men collected data pertaining to their specialties, and ana- lyzed and interpreted those data with the aid of other data collected during the survey, as well as information obtained in earlier work in this part of the Colorado River basin. The technical report will be comprised of contributions by these men--27 authors in all-in which the data of the comprehensive survey will be described, analyzed, and interpreted.

This circular constitutes a summary of the principal findings of the comprehensive survey; details of procedures and equipment used have been omitted. The author took no part in the field work of the comprehensive survey, and his chief involvement has been as technical editor of the advance report. The ideas and conclusions expressed in the circular are those of the authors of the pertinent sections of the technical report, but the author of the circular accepts responsibility for any errors of judgment in quoting or otherwise summarizing the parent material. 


\section{CONTENTS}

Abstract

Environment of Lake Mead.

Geologic setting of Lake Mead, by C. $\mathbf{R}$ Longwell

Tributary drainage basin, by H. E. Thomas.

Scope and program of the comprehensive survey....

Geodetic surveys

Interpretation of the leveling data by $\mathrm{C}$. Longwell.

Hydrographic surveys............................. the reservoir, by Gunnar Liefson and F. C. Ames.

Method of hydrographic surveying of the lake, by Gunnar Leifson.

Horizontal control, by R. M. Wilson..............

Vertical control, by F. C. Ames...............

Evaluation of the echo sounding, by G. B. Cummings

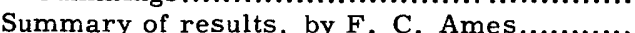

Survey of the Lower Granite Gorge, by

L. C. Pampel.

Reservoir storage.

Significance of area, capacity, and sediment tables, by J. W. Stanley....

Computations and tables, by J. L. Speert, F. C. Ames, F. W. Kennon, and W. B. Langbein
Lake and Lower Granite Gorge portions of

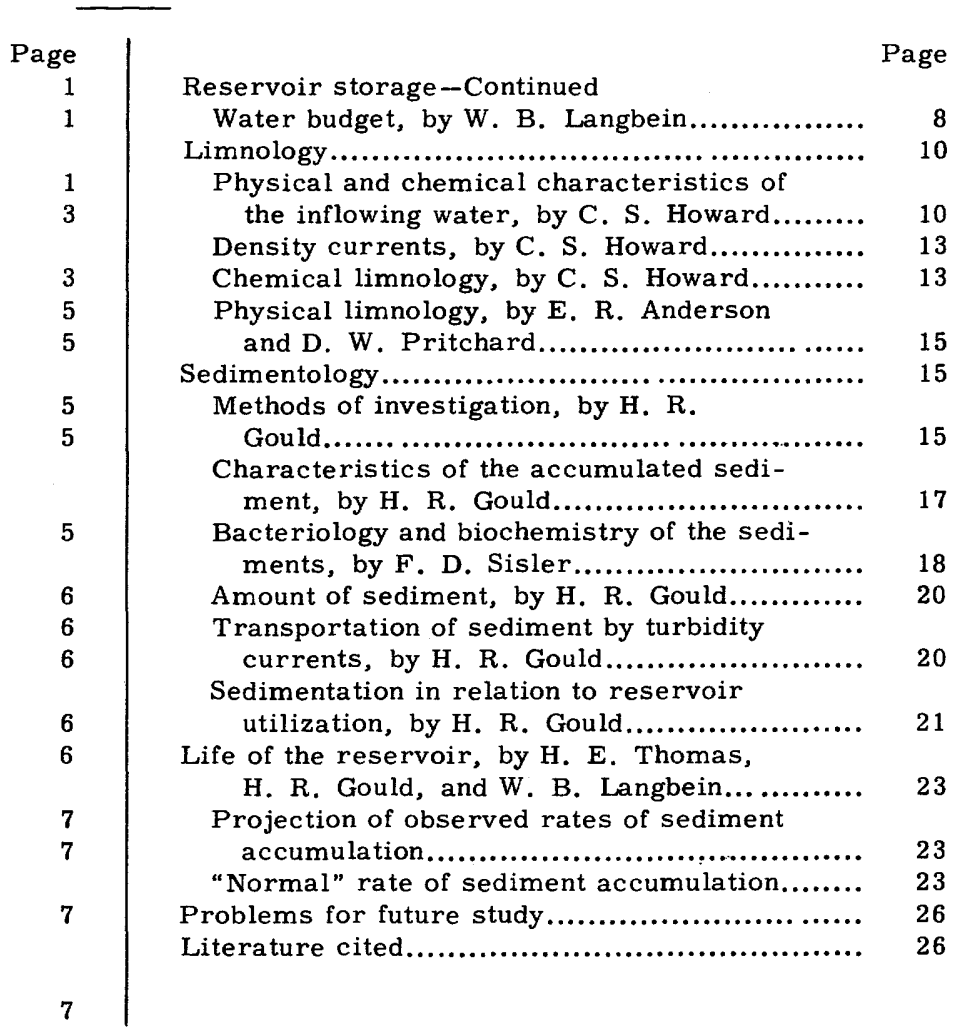

\section{ILLUSTRATIONS}

Page

Plate 1. Annual profiles of the delta along Colorado River channel through Lake Mead.

Facing 18

Figure 1. Map of Colorado River basin, showing location of Lake Mead...

2. Sediment carried by Colorado River in water years 1931-50.

3. Contours showing chariges in altitude, 1935-50

4. Stage and usable storage of Lake Mead, 1935-48.

5. Relation of annual runoff to sediment load at Grand Canyon.

6. Periods of reported density currents and elevation of top of sediment near Hoover Dam, 1935-50

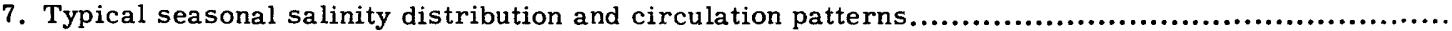

8. Specific weight of sediment in the Colorado delta

9. Actuarial projections for Lake Mead. 
VI

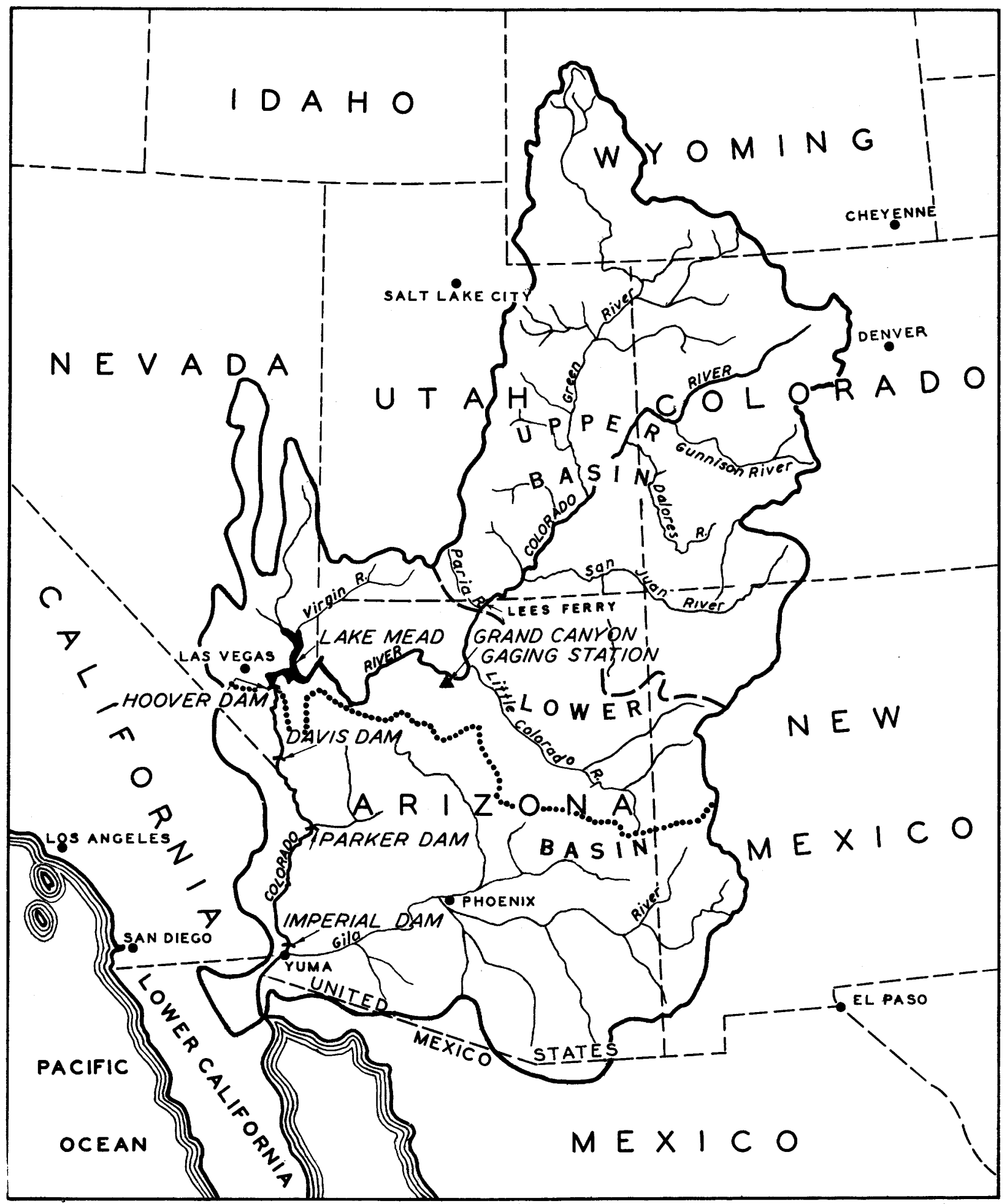

Figure 1. --Map of Colorado River basin, showing location of Lake Mead. 


\title{
FIRST FOURTEEN YEARS OF LAKE MEAD
}

\author{
By Harold E. Thomas
}

\section{ABSTRACT}

This circular summarizes the results of recent studies of Lake Mead and its environs. Area-capacity tables, prepared on the basis of a hydrographic survey of the lake in 1948-49, show that the capacity of the reservoir was reduced 4.9 percent during the first 14 years after Hoover Dam was completed, but the usable capacity was reduced only 3.2 percent. Practically all of this reduction was caused by accumulation of sediment in the reservoir. Studies of inflow and outflow indicate that the reservoir has a total storage capacity about 12 percent greater than that shown by the areacapacity table, because of "bank" storage, or groundwater storage in the bottom and sides of the reservoir. Thus the total capacity in 1949 was greater than the quantity shown by the original area-capacity table, even though large quantities of sediment had been deposited in the reservoir during the 14 years.

According to computations of the volume and weight of the accumulated sediment, about 2,000 million tons were deposited in the reservoir by the Colorado River in 14 years; this is within 2 percent of the amount calculated from measurements of the suspended sediment carried by the inflowing rivers. It is estimated that the sediment capacity of the reservoir, when filled to the level of the permanent spillway crest, is about 75, 000 million tons. The sediment contributed by the Colorado River averages about 45 percent sand and 55 percent silt and clay.

If the sediment carried by the river in the years 1926-50 represents the long-term average rate of accumulation in Lake Mead, it will be a century before the sediment at the dam reaches the level of the lowest gates in the intake towers, and more than 4 centuries before the reservoir is filled with sediment to the level of the permanent spillway crest. The rate of sedimentation since the first year of Lake Mead (1935) has been about 20 percent lower, and if that rate continues in the future, the life of the reservoir will be correspondingly greater. Construction of upstream reservoirs to capture some of the inflowing sediment, or transportation of sediment in the outflow through Hoover Dam, would also increase the life of the reservoir.

In the first 12 years of Lake Mead, the dissolved mineral matter in the outflowing water was significantly greater than the average in the inflowing water, owing in part to solution of gypsum and rock salt from the bed of the reservoir. Currently the increased dissolved solids in the outflowing water can be accounted for almost entirely by evaporation from the reservoir, which is about 5 to 7 percent of the annual inflow. The water from Lake Mead is habitually of better quality than that diverted from the river for irrigation prior to regulation by Hoover Dam, because it represents an average of the poor water of low stages and the excellent water from melting snow.

Geodetic surveys of the Lake Mead area show that the weight of water has caused subsidence of the earth's crust amounting to about 120 millimeter at Hoover Dam, and an even greater amount in the principal area of storage in the reservoir.

\section{ENVIRONMENT OF LAKE MEAD}

Lake Mead is the reservoir formed by Hoover Dam on the Colorado River, and it covers parts of southeastern Nevada and northwestern Arizona (fig. 1). The lake is in the Lower Basin of Colorado River, as defined by the Colorado River Compact of 19221 /. Hoover Dam is about 355 river-miles downstream from Lees Ferry, Ariz., which marks the lower limit of the Upper Basin of Colorado River.

Hoover Dam provides the regulation necessary for ef fective operation of the downstream reservoirs created by Davis Dam, Parker Dam, and Imperial Dam. Lake Mead also provides practically all the water that is developed from the river in Lower Basin, for there is negligible inflow from Gila River, Bill Williams River, and other tributaries that enter the Colorado River below Hoover Dam.

\section{Geologic Setting of Lake Mead, by C. R. Longwell}

From the mouth of the Grand Canyon the Grand Wash Cliffs extend far northward and southeastward, marking the abrupt western edge of the Colorado Plateaus. Between the cliffs and Hoover Dam there are mountain ridges that trend generally north, and intervening wide valleys. The Colorado River has cut deep canyons

1/ The agreement concerning the apportionment of the use of the waters of the Colorado River System dated November 24, 1922, executed at Santa Fe, N. Mex., by Commissioners for the States of Arizona, California, Colorado, Nevada, New Mexico, Utah, and Wyoming, approved by Herbert Hoover, representative of the United States of America, and proclaimed effective by the President of the United States of America, June 25, 1929. 


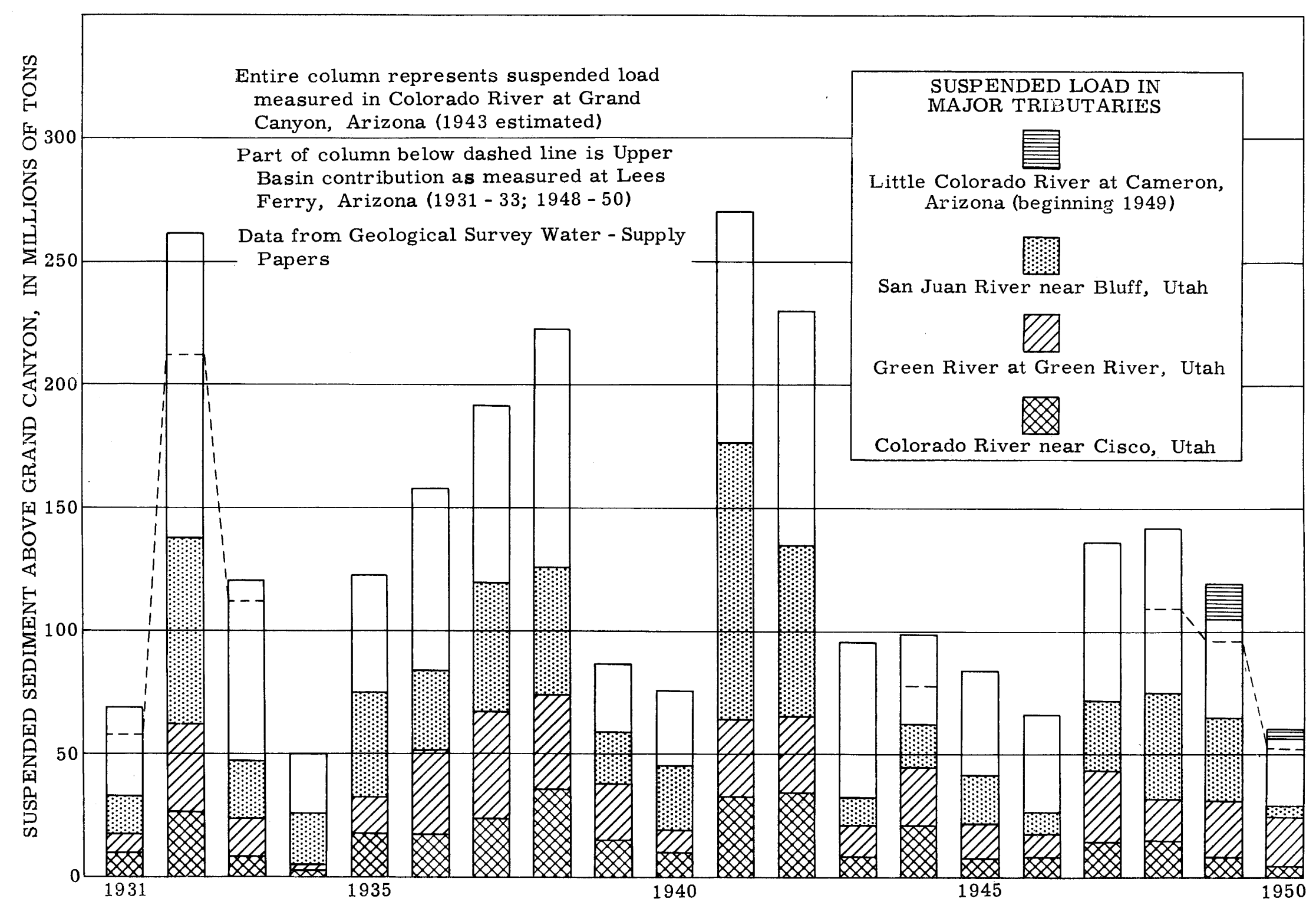

Figure 2. --Sediment carried by Colorado River in water years 1931-50. 
through the mountain ridges, whereas in the adjacent basins the river valley is comparatively wide and low walled. Accordingly, the main body of Lake Mead consists of alternating narrow and wide segments.

The rocks of the highlands are in general older and more resistant than those flooring the basins. These older rocks are well exposed in the canyon sections of Lake Mead. The younger basin deposits are in general inconspicuous, since they are either covered by the lake water or form slopes and low hills bordering the lakeshore.

The most exiensive of the sedimentary beds in the basins are those of the Muddy Creek formation, chiefly sand, silt, and clay in thin regular layers that suggest deposition in shallow lake water. The formation includes beds of gypsum and rock salt, and these soluble salts crop out in the floor of the reservoir in extensive areas.

The Colorado River was dammed during the Pleistocene epoch and formed a lake that was deeper and more extensive than Lake Mead. The location of this prehistoric dam-or other cause of ponding-is not known, but Longwell's description of the Chemehuevi formation indicates a pattern of delta deposition similar to that which has begun since the completion of Hoover Dam. The lower part of the formation consists chiefly of banded clay, presumably deposited as bottomset beds in a deep lake. This clay is thin in Iceberg Canyon and thicker downstream; extensive remnants occur near Davis Dam, about 60 miles below Hoover Dam. Sand overlies the clay, and comprises most of the thickness of the formation in upstream areas. The upper part of the formation consists of river gravel and cobbles, presumably deposited after the lake was filled. Some of these gravels are about 300 feet above the high-water level of Lake Mead. The cobbles in the upper part of the Chemehuevi formation were transported by a larger and more powerful stream than the present Colorado River, which apparently carries nothing coarser than fine gravel into the deltaic fill in the Lower Granite Gorge.

\section{Tributary Drainage Basin, by H. E. Thomas}

The water and sediment that accumulate in Lake Mead come from an area of about 168,000 square miles, or 5 percent of the United States. This tributary basin includes some areas that have very high rates of runoff, and other areas that yield very little water to the Colorado River; in certain areas the streams are generally clear, whereas other areas contribute much sediment to Lake Mead.

Most of the runoff is derived from melting of snow in the higher mountains, but considerable quantities of water move for at least a short distance through the soil or underlying ground-water zones before reaching the river. Most of the dissolved material in the river is derived from ground water rising as springs and seeps along the main stem and tributary channels, and return flow of irrigation water.

The geologic formations cropping out within the drainage basin are also the ultimate sources of the sediment carried by the Colorado River and its tributaries. Only an insignificant part of the sediment, however, comes directly from rock outcrops. The main stream and tributaries rarely come in contact with bedrock except in their headwaters, for generally, the bed and banks of the larger channels are formed of stream-borne sediment, or alluvium. These alluvial deposits constitute the immediate source of much of the sediment now moving toward Lake Mead. The bulk of Lake Mead sediment comes from the arid parts of the drainage basin in New Mexico, southern Utah, Arizona, and Nevada.

Long-term records of suspended sediment are available at four stations in the tributary drainage basin. These records indicate that the sediment transported during the water year 1948 was close to the average annual load in the period 1930-48. Probably more than 95 percent of the sediment entering Lake Mead passes through the Grand Canyon. The annual variations in suspended load at Grand Canyon and the proportions of the load that pass the three upstream stations are depicted in figure 2 .

In the period of record at Grand Canyon, the year of highest runoff (1929) was also the year of greatest suspended sediment load, and the year of least runoff (1934) was the year of least sediment transportation. There are striking variations in the proportions of the load that pass the three upstream stations from year to year, although it is generally true that the San Juan River carries less water and more sediment than either the Green River or the Colorado River above its junction with the Green River.

\section{SCOPE AND PROGRAM OF THE COMPREHENSIVE SURVEY}

The Lake Mead survey was essentially a reservoir survey needed primarily for operational purposes, but its scope far surpassed that of other reservoir surveys undertaken in the past. The Office of River Control, of the Bureau of Reclamation, is responsible for operation and construction for physical control of the Colorado River in Lower Basin, and is authorized by Congress to sponsor investigations that will provide the data needed for these activities. Although the need for surveys of sedimentation and salinity was recognized before the lake first filled to capacity in 1941, no definite plans could be made until World War II had ended.

The basic requirements for surveys of sediment and salinity developed into the comprehensive survey. Thus, a hydrographic survey was undertaken to provide new area-capacity tables and also to derive, by difference from the pre-Lake Mead data, the volume of accumulated sediment. The characteristics of the sediment and the processes by which it was transported and deposited were also investigated, and some of these characteristics led to intensive studies by the Scripps Institution of Oceanography of the biochemistry and bacteriology of sediments near Hoover Dam. Data concerning the salinity were obtained largely during monthly cruises under the direction of the Navy Electronics Laboratory, and the circulation in the lake was established from the salinity distribution. A preliminary energy budget was also developed, and from it an es timate of evaporation was obtained. Precise leveling by the Coast and Geodetic Survey provided the basis for estimating the deformation of the earth's crust caused by storage in Lake Mead. 


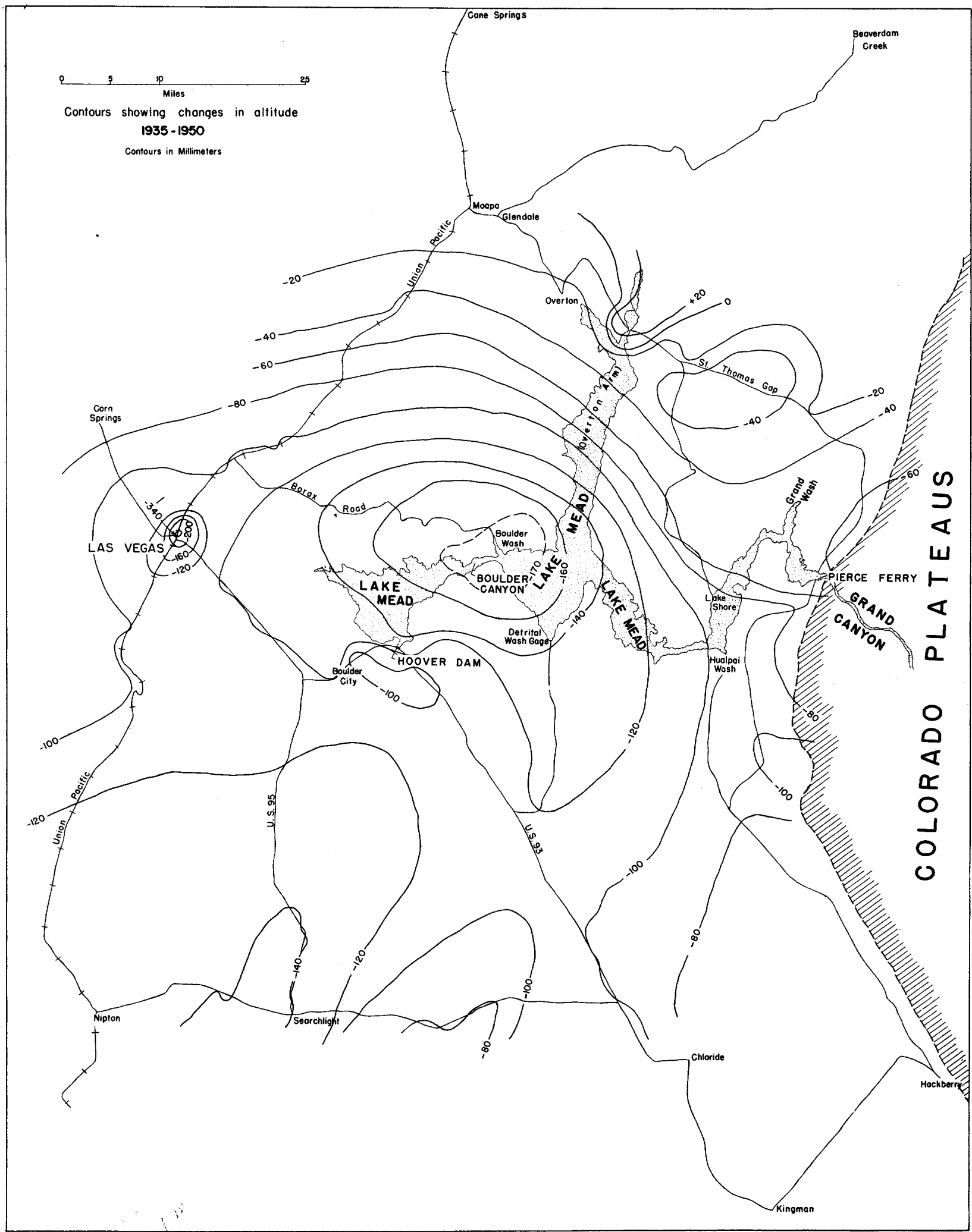




\section{GEODETIC SURVEYS}

\author{
Precise Leveling, by E. J. Parkin
}

The precise leveling in the Lake Mead area was done by the Coast and Geodetic Survey for the purpose of measuring the deformation of the earth's crust resulting from the load of impounded water. The Hoover Dam level net was established in 1935, and levels were first run in March and April of that year, when the reservoir had just begun to fill. The elevations therefore represent the conditions at the time of nearly minimum load. The level net was rerun in 1940-41, when storage in the reservoir was about 85 percent of capacity. The latest leveling was in 1949-50; the reservoir storage at that time was less at all times than during the 1940-41 leveling. For determination of the effect of reservoir load upon the earth's crust, a special adjustment was made of the data obtained in each period of leveling, holding fixed the elevation of only one bench mark. All three sets of elevations derived by this special adjustment are based on the same elevation of bench mark R1 at Cane Springs, Nev.

\section{Interpretation of the Leveling Data, by C. R. Longwell}

The changes in elevation during the intervals between leveling are shown graphically in figure 3 . A conspicuous feature is a broad basinlike depression centering in the vicinity of Boulder Canyon. The general form of this depression remained unchanged from 1940-41 to 1949-50, although the area as a whole continued to subside during that interval, and a pronounced regional tilt extended apparently beyond the southern limit of the level net. During the interval 1935-41 the general tilt was southeastward. Between 1941 and 1950 the total area affected by subsidence was considerably enlarged, with overall tilting toward the southwest. The basin centering near Boulder Canyon was retained but not appreciably deepened.

The basinlike subsidence centering about Boulder Canyon appears to have resulted from storage of water in Lake Mead. More than 60 percent of this water, as much as 25 billion tons, is stored in the wide Virgin and Boulder Basins that lie directly east and west of Boulder Canyon. The total area of these basins is about 85 square miles, and the load added to this area averages more than 10 tons per square foot. Since the two long arms of the lake diverge at a large angle from the Virgin Basin east of Boulder Canyon, the center of gravity of the lake lies in the vicinity of this basin in a very real sense. The extensive tilting subsidence, involving the entire lake basin and extending at least tens of miles farther south, is probably connected with a regional movement that may have been in progress before the dam was built.

With reference to bench mark $R 1$ at Cane Springs, Nev., the ten bench marks on Hoover Dam dropped an average of 60 millimeters between 1935 and 1941 , and 62 millimeters farther between 1941 and 1950 , a total subsidence of 0.4 foot. If there had been no change in the elevation of the reservoir bottom, this lowering of the dam would have had the effect of reducing the capacity of the reservoir at spillway level by approximately 60,000 acre-feet. However, subsidence has exceeded 120 millimeters (the amount of subsidence at the dam) in an area that comprises more than 60 percent of the total area of the reservoir; nearly 75 percent of the water is stored within this area when Lake Mead is filled to spillway level, and the proportion increases with decreasing lake stage. Thus the change in overall capacity due to subsidence is doubtless of very small magnitude.

Since 1941 the dam has been lowered more than any of the six locations where the level net provides data as to elevations near the shore of the reservoir. The leveling of 1941 occurred while the reservoir was filled nearly to capacity, and the differential rise at these six locations by 1950 may be an indication of elastic rebound with reduced load.

\section{HYDROGRAPHIC SURVEYS}

Lake and Lower Granite Gorge Portions of the Reservoir, by Gunnar Liefson and F. C. Ames

The hydrographic survey of Lake Mead was undertaken to obtain the data necessary for determination of the volume and distribution of sediment, and the occurrence and extent of other changes in reservoir boundaries; and for the preparation of new reservoir area and capacity tables.

Lake Mead is filled to its capacity for controlled storage when it reaches the level of the spillway gates in raised position, $1,221.4$ feet above sea level. The highest lake level yet reached was $1,220.4$ feet on July 29 and 30,1941 , at which time the lake formed a level pool extending 120 miles upstream from Hoover Dam to the Bridge Canyon rapids in the Lower Granite Gorge of Grand Canyon. At lower lake stages the river flows into the lake farther and farther downstream in the Lower Granite Gorge and in Pierce Bașin. River rather than lake conditions prevail in the Lower Granite Gorge the greater part of the year. Within the Lower Granite Gorge there is an abrupt change at the foot of the Bridge Canyon rapids from a relatively steep, canyon-type stream, to a stream with a typically wide, shallow cross section and meandering alinement. Near Bridge Canyon these meanders are still controlled largely by the canyon alinement; but in the lower reaches the lowwater channel, 200 to 400 feet wide, meanders across a sediment "flood plain" as much as 2, 200 feet wide.

The water in the canyon section is always sediment laden. The lower 65 miles of the reservoir (80 rivermiles) between Pierce Ferry and Hoover Dam is essentially a chain or series of relatively wide basins, connected by short, narrow canyon sections. In this part of the reservoir, lake conditions exist at all stages, with depths ranging up to 450 feet and widths ranging from a minimum of 650 feet in Boulder Canyon to about 5 miles in the basin areas. The water is generally clear and the only velocities are the very low ones resulting from circulation of water in the lake and those induced by density-current action (p. 13, 20).

The lake is divided naturally into two parts, each requiring different surveying techniques and different types of equipment. In the Lower Granite Gorge the methods were essentially those of land surveying, with soundings across the river channel to complete the valley cross section. In the main part of the lake the methods were those of deep-water hydrographic surveying. 
Method of Hydrographic Surveying of the Lake, by Gunnar Leifson

In the hydrographic survey of the lake, depths were measured by automatic recording echo sounders, and the position of the sounding boat was fixed at regular intervals along the sounding line. Lake Mead provided an exceptional opportunity for comparison of hydrographic with topographic surveys. The echo-sounding profile and the corresponding cross section derived from topographic maps that had been prepared prior to the filling of the lake are in close agreement.

\section{Horizontal Control, by R. M. Wilson}

The triangulation during 1947-48 had several purposes: first, to recover triangulation stations set by Fairchild Aerial Surveys for control of the 1935 topographic maps made for the Soil Conservation Service (U. S. Department of Agriculture, 1935) and to test the precision of their coordinates; second, to tie in points of other previous surveys wherever possible, so that all these surveys might be coordinated on a common datum; and third, to establish convenient reference points for the 1948-49 hydrographic survey and to mark them permanently so that future surveys can be referred to the same points.

Altogether, 336 new reference points and triangulation stations were established, most of them just above the high-water mark of the reservoir. About 35 navigation lights or other objects were located by intersection, 15 stations of the Coast and Geodetic Survey were recovered and occupied, and 33 stations established in previous surveys were tied in. The position closures involved in all these ties indicate excellent work in the earlier triangulation in this area. Analysis discloses that the triangulation of 1935 is dependable and accurate, and entirely adequate for the purposes of this investigation, some of which required a higher order of accuracy than that required for use in making the maps under the 1935 contract.

\section{Vertical Control, by F. C. Ames}

Vertical control was required in the hydrographic survey of Lake Mead for conversion of the sounded depths to the corresponding bottom elevations above a selected reference plane or datum. All soundings were referenced to the water surface at the time and place of sounding, and a prerequisite for vertical control was the collection of adequate records of the water-surface elevation at those times and places. A permanent gage at Hoover Dam provides a continuous record of watersurface elevations at the dam. This record was sufficiently accurate to be used without adjustment for conversions of sounded depths to bottom elevations.

\section{Evaluation of the Echo Sounding, by G. B. Cummings}

The sonar equipment and methods used to determine the depth of water and thickness of sediment in Lake Mead are based on the echo-sounding principle; a pulse of sound energy is emitted from a projector, travels through the water, is reflected and returns as an echo to the projector which has been arranged in the meantime to receive the echo. This echo can be recorded in various ways, such as on a cathode ray screen or on the paper chart of a recorder.

The equipment operating at 50 kilocycles gave a consistent indication of the top of the sediment, within 2 feet of accuracy. Waves of this frequency did not penetrate the sediment layer. Where the sediment was very thin, the trace of the interface was slightly fuzzy. Independent determinations showed that the transition layer was 1 to 4 inches thick. The instruments operating at 14.25 kilocycles produced an echo from the sediment. surface and, where the sediments were dominantly clay, an echo from the bottom of the old river bed. In the Boulder Basin, penetration of 100 feet of soft sediment was obtained. The depths obtained by the Navy sonar depth-sounding equipments were in close agreement with the results obtained by cable-and-reel depth measurements where the depths permitted the latter observations to be made.

\section{Summary of Results, by F. C. Ames}

The sounding records revealed a range of depths up to about 74 fathoms (444 feet). The elevation of the sediment surface was lowest at the dam. The thickness of sediment along the center line of the former river channel was more than 100 feet at the dam, diminishing to 45 feet in the Temple Bar area, and then increasing to a maximum of 270 feet near Pierce Ferry. In the Boulder Basin, where both the sediment surface and the prelake topography were recorded on the sound traces, the indicated elevations of the prelake topography checked the 1935 map elevations very closely.

Nearly all of the significant changes in reservoir bottom between 1935 and 1948 have resulted from deposition of sediment by the Colorado River; in the reservoir west of longitude $113^{\circ} 57^{\prime}$, covered by the deepwater or "lake" survey, the accumulated sediment from the river is about 850,000 acre-feet. The Virgin River has built up a delta containing 34,000 acre-feet of sediment. In contrast to the Colorado River, however, there was no evidence of any significant amount of sediment in the old Virgin River channel below the toe of the delta. No measurable quantity of sediment was found in any part of the old Muddy Creek channel.

Aside from sediment accretion Lake Mead has, in general, remained relatively unchanged since the original survey in 1935. Only four slump areas of any consequence were noted, three in Boulder Basin and one in Virgin Canyon. The largest of these involved an area along the north shore of Boulder Basin, where lateral displacements between original and new contours amounted to several hundred feet. About 12,000 acrefeet of earth between elevations 925 and 1,220 feet slumped downward, of which some probably came to rest below the present sediment surface at elevation 750 feet.

Stream erosion since 1935 has been great enough in only one locality to cause an appreciable increase in the reservoir area. At the mouth of Detrital Wash the channel above the average lake level has been scoured in places to depths of about 10 feet. Some minor alterations of shoreline are clearly attributable to wave action, particularly along a few steep-sided headlands of rather loosely cemented sand and gravel, which are subject to undercutting and caving. Except for these 
headlands and the rock-walled canyons, the lakeshore is moderately sloping and not subject to serious undercutting and caving. Caving above the high-water line at elevation 1, 220 feet is rare, and the reservoir capacity has not been decreased significantly by wave action.

\section{Survey of the Lower Granite Gorge, by L. C. Pampel}

The upper section of Lake Mead, the Lower Granite Gorge, is approximately 40 miles long, extending between Bridge Canyon and a point just above Pierce Ferry. At the maximum designed pool elevation of 1,229 feet, the water-surface area in the Lower Granite Gorge is about 3 percent of the whole lake, and the original storage capacity in this section was about 2 percent of the total lake capacity. However, the 194849 survey indicates that this gorge section contains about one-third of the total sediment deposited in Lake Mead up to that time.

In the Lower Granite Gorge survey, the position of the sediment surface was determined with respect to an overhead reference plane corresponding to the maximum designed water-surface elevation, and the computations led first to a determination of the amount of original capacity that was not filled with sediment in 1948. The volume determinations were based on 175 cross sections. Excepting the six sections farthest upstream and nearest to Bridge Canyon rapids, these sections were spaced at intervals of 620 to 2,260 feet (averaging 1, 220 feet) throughout the Lower Granite Gorge.

As in the lake survey, adequate horizontal and vertical control was essential in the Lower Granite Gorge for accurate determinations of the positions of the sediment surface at each point of measurement. The horizontal control was based on the Fairchild triangulation net established in 1935 and on a net established by the Bureau of Reclamation in 1942 for use in the Bridge Canyon investigations. The vertical control was based on bench marks set by the Bureau of Reclamation for use in its Bridge Canyon investigations.

The total remaining storage capacity in the Lower Granite Gorge up to elevation 1,229 feet was found to be 219,000 acre-feet. The original storage capacity of the Lower Granite Gorge was computed by the Soil Conservation Service to be 760,000 acre-feet. The amount of sediment deposited in the Lower Granite Gorge since the closure of Hoover Dam was determined by subtraction to be 541,000 acre-feet.

The thickness of sediment varies from none at the foot of the Bridge Canyon rapids to 16 feet at the Bridge Canyon dam site and to a maximum of 270 feet near the junction of the canyon section with the main lake. The profile of the center of the stream in 194849 had a uniform slope of about 1.25 feet per mile in a 27-mile reach below Separation Canyon. The profile of highest sediment deposition in the Lower Granite Gorge also has a slope of about 1.25 feet per mile. Many of the highest sediment surfaces in the gorge probably were formed in 1941 and 1942 , when Lake Mead reached maximum elevations of $1,220.4$ and $1,213.5$ feet respectively.

\section{RESERVOIR STORAGE}

Significance of Area, Capacity, and Sediment Tables, by J. W. Stanley

The functions of river regulation and flood control are in the first priority among the purposes for which Hoover Dam was authorized. To assure that the desired flood control can be accomplished, the upper 59 feet of controlled storage in the original reservoir was reserved for flood control, and storage for other purposes must not reach into this reserved zone as of April 1 of each year. By August 1 only the upper 8 feet was reserved for protection against floods. Any sediment deposited in this upper part of the reservoir since 1935 , even in the zone of uncontrolled storage, reduces the lower limit of the flood-control reserve, and therefore the upper limit of the storage available for other purposes. Accurate area-capacity data for the upper levels of Lake Mead are thus necessary to determine the lower limit of the flood-control reserve.

Second in priority among the purposes of Hoover Dam and Lake Mead is the combined function of irrigation and domestic uses. In 1950 the annual release required from Hoover Dam for downstream use was approximately 6,600,000 acre-feet, which includes losses in transit by evaporation, transpiration, and seepage. It may become necessary during years of minimum inflow to limit releases from Hoover Dam to those required by downstream interests, thus curtailing power generatiun.

Last in priority among the functions of Lake Mead and Hoover Dam is hydroelectric power generation. In spite of this low priority, the revenue derived from the sale of electrical energy must repay the cost of the dam and appurtenant works. Accurate area-capacity information for all elevations of Lake Mead is necessary to translate forecasts of future inflow into terms of hydrostatic head on the powerplant and thereby into water releases necessary to generate the energy required to meet estimated future loads. Further, the amount of water stored in the reservoir in the elevation band usable for power generation must be known in order to maintain at all times enough reserve storage water to permit generation of the firm obligation under conditions established in the contracts with the several power allottees.

Computations and Tables, by J. L. Speert,

\section{F. C. Ames, F. W. Kennon, and W. B. Langbein}

Tables in the technical report show the lake-surface area in acres for 1 -foot increments in water-surface elevation; the usable capacity (above lowest outlets at intake towers) for similar increments of elevation; the reservoir volumes and sediment deposition in individual basins of the reservoir, by 10 -foot increments of elevation; and comparison of the areas and capacities in 1935 and 1948 and the accumulation of sediment during the 14-year interval.

Table 1 summarizes the significant items of change between 1935 and 1948. It shows the elevations above mean sea level of various features of operational significance, both with respect to powerhouse datum and 
Table 1. -Comparative summary, 1935 and 1948-49

Changes in elevation and capacity

\begin{tabular}{|c|c|c|c|c|}
\hline \multirow[t]{2}{*}{. } & \multicolumn{2}{|c|}{$\begin{array}{c}\text { Elevation } \\
\text { (feet above mean sea level) }\end{array}$} & \multicolumn{2}{|c|}{$\begin{array}{c}\text { Capacity } \\
\text { (acre-feet) }\end{array}$} \\
\hline & $\begin{array}{c}\text { Powerhouse } \\
\text { datum }\end{array}$ & $\begin{array}{l}\text { Datum of } 1929 \\
\text { levels of } 1935\end{array}$ & Original & $1948-49$ survey \\
\hline Maximum designed water surface................ & 1229.00 & 1229.55 & $32,471,000$ & $31,047,000$ \\
\hline Top of spillway gates-raised $\ldots \ldots \ldots \ldots \ldots \ldots \ldots \ldots \ldots \ldots \ldots \ldots \ldots$ & 1221.40 & 1221.95 & $31,250,000$ & $29,825,000$ \\
\hline Flood control level August $1,1935 \ldots \ldots \ldots \ldots \ldots \ldots \ldots \ldots \ldots$ & 1213.17 & 1213.72 & $29,965,000$ & ................... \\
\hline Flood control level August $1,1948 \ldots \ldots \ldots \ldots \ldots \ldots \ldots \ldots \ldots \ldots$ & 1213.14 & 1213.69 & & $28,547,000$ \\
\hline Permanent spillway crest....................................... & 1205.40 & 1205.95 & $28,794,000$ & $27,376,000$ \\
\hline Flood control level April 1, $1935 \ldots \ldots \ldots \ldots \ldots \ldots \ldots \ldots \ldots \ldots$ & 1162.83 & 1163.38 & $22,958,000$ & ................. \\
\hline Flood control level April $1,1948 \ldots \ldots \ldots \ldots \ldots \ldots \ldots \ldots \ldots \ldots \ldots$ & 1162.19 & 1162.74 & $\ldots \ldots \ldots \ldots \ldots$ & $21,547,000$ \\
\hline 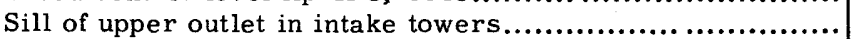 & 1045.00 & 1045.55 & $11,162,000$ & $10,222,000$ \\
\hline 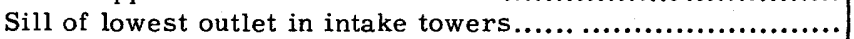 & 895.00 & 895.55 & $3,223,000$ & $2,620,000$ \\
\hline
\end{tabular}

Storage of water and sediment, in acre-feet

\begin{tabular}{|c|c|c|c|c|}
\hline & \multicolumn{2}{|c|}{1935} & \multicolumn{2}{|c|}{1948} \\
\hline & Water & Sediment & Water & Sediment \\
\hline Flood-control reserve, August $1 \ldots \ldots \ldots \ldots \ldots \ldots \ldots \ldots \ldots \ldots \ldots$ & $2,500,000$ & 0 & $2,500,000$ & 8,000 \\
\hline Permissive usable contents, August $1 \ldots \ldots \ldots \ldots \ldots \ldots \ldots \ldots \ldots$ & $26,748,000$ & 0 & $25,927,000$ & 815,000 \\
\hline 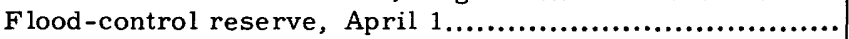 & $9,500,000$ & 0 & $9,500,000$ & 99,000 \\
\hline 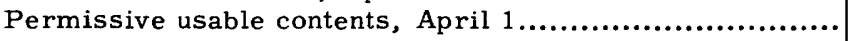 & $19,748,000$ & 0 & $18,927,000$ & 724,000 \\
\hline 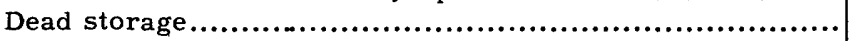 & $3,223,000$ & 0 & $2,620,000$ & 603,000 \\
\hline Total storage below permanent spillway crest................ & $28,794,000$ & 0 & $27,376,000$ & $1,418,000$ \\
\hline Total storage below spillway gates in raised position......... & $31,250,000$ & 0 & $29,825,000$ & $1,425,000$ \\
\hline Usable storage below permanent spillway crest............... & $25,571,000$ & ............... & $24,756,000$ & $\ldots \ldots \ldots \ldots \ldots \ldots \ldots$ \\
\hline Usable storage below spillway gates in raised position....... & $28,027,000$ & & $27,205,000$ & $\ldots \ldots \ldots \ldots \ldots \ldots$ \\
\hline
\end{tabular}

the datum of 1929 , leveling of 1935 . The significant changes in storage of water and sediment are also summarized. Thus the maximum storage controlled by the spillway gates in raised position decreased from $31,250,000$ acre-feet in 1935 to $29,825,000$ acre-feet in 1948. The required August 1 flood-control reserve extended less than half an inch lower in 1948 than in 1935 , although the usable storage below that level decreased 815,000 acre-feet because of sediment deposition. However, the April 1 flood-control reserve by 1948 required an additional 0.64 -foot layer of the reservoir as a result of deposition of 99,000 acre-feet of sediment in the upper part of the reservoir, chiefly in the Lower Granite Gorge. The dead storage, below the lowest outlet in the intake towers, was decreased 603,000 acre-feet during the 14-year interval, because of deposition of sediment.

\section{Water Budget, by W. B. Langbein}

The water budget of Lake Mead is an account of its operation for the basic function of regulating the highly variable flow of Colorado River for the benefit of flood control, irrigation, domestic use, and hydroelectric power generation. This regulation of the flow is brought about through storage of water in years of high runoff to supplement the flow during years of low runoff (fig. 4).

Lake Mead in 1935 had a usable capacity of more than $28,000,000$ acre-feet, which by 1948 had been reduced to $27,200,000$ acre-feet because of sediment deposition. The annual inflow into the lake in the 14- year period since Hoover Dam was completed (1935-48 inclusive) averaged about $13,000,000$ acre-feet. The usable capacity, therefore, has been equal to 215 percent, and is still 210 percent of the average yearly flow through the reservoir. This storage ratio is indicative of a long detention time for river regulation and control.

Setting up the water budget of the lake requires an accounting of all items of inflow, outflow, and storage. The shortest practical period for which the budget can be set up is a year. Most of the inflow to the lake is measured at the gaging station on Colorado River near Grand Canyon, 145 river-miles above Lake Mead, and the inflows from Bright Angel Creek and Virgin River are also measured. The sum of these three constitutes the measured inflow. There is about 25,000 square miles of tributary area from which the runoff into the lake is unmeasured; this unmeasured inflow is estimated by statistical analysis to be a maximum of 3 percent and to average about $1 \frac{1}{2}$ percent of the measured inflow. The precipitation on the lake is computed from the rainfall recorded at three locations around the lake, multiplied by the mean surface area during each year. In the year of greatest annual precipitation, 1941, the computed precipitation on the reservoir was considerably less than 1 percent of the measured inflow from tributaries.

The water released through Hoover Dam constitutes nearly all of the outflow from Lake Mead, and this is measured at a gaging station 1 mile below the dam. Evapotranspiration constitutes the only other important item of outflow from the lake. Evaporation is small in 


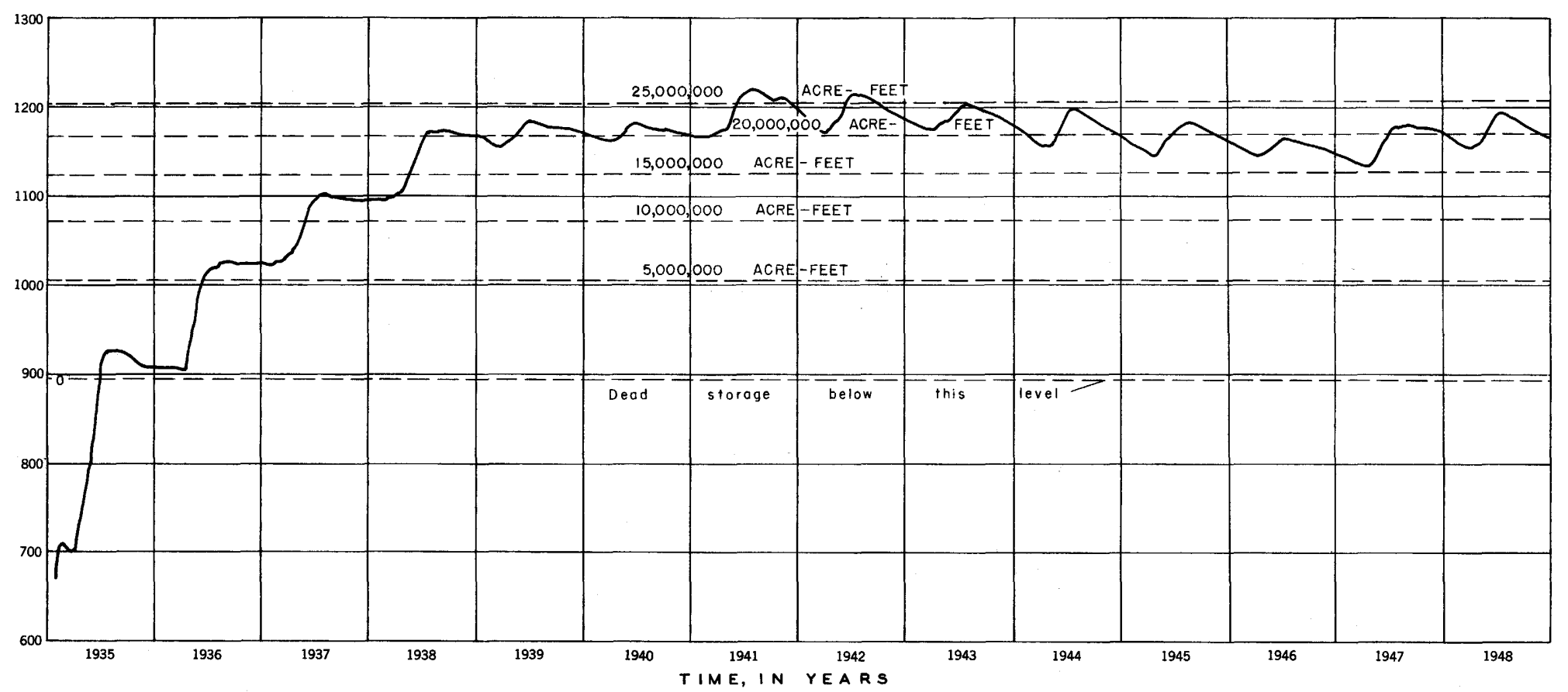

Figure 4. --Stage and usable storage of Lake Mead, 1935-48. 
comparison with the measured outflow -about 5 to 7 percent of the annual discharge through the dam. Nevertheless, it is one of the largest unmeasured items in the water budget, for it is considerably greater than the unmeasured inflow and 10 to 30 times as great as the addition by precipitation.

The estimates of evaporation used in the water budget are obtained by statistical analysis of available data; they assume a constant annual rate of evaporation of 6.0 feet per year, which ignores the variation in climate from year to year. The inadequacy of these estimates is fully recognized, and they were used in the technical report as an interim measure, with the assurance that they will be superseded by more accurate determinations on the basis of recent research at Lake Mead.

The water budget shows that on an annual basis more water enters into or is withdrawn from storage in Lake Mead than is indicated by the capacity table. In other words, Lake Mead has a significant amount of storage space in addition to the volumes calculated from the hydrographic survey of 1948-49, or even the original reservoir survey of 1935 . The unsurveyed storage in Lake Mead represents the volume of water that can be stored in the reservoir bottom and sides as determined during the hydrographic survey of 1948-49. It corresponds to bank storage along a river, with all the phenomena of filling and draining of interstices as the lake rises and recedes. It includes the water in the volume that has been filled by sediment during the interval from 1935 to 1948 , and it includes voids in the gravel and sand, and other rock materials that underlie the bed and sides of the reservoir.

The magnitude of this bank storage, or ground-water storage, is indicated by comparison of the reservoir storage as indicated by capacity table and the total storage as computed by difference between outflow and inflow. As of September 30, 1941, the total storage computed from inflow-outflow differences was 33, 000, 000 acre-feet, compared with reservoir contents of 29, 400,000 acre-feet as compiled from the original capacity curve. The difference of about $3,600,000$ acre-feet is presumed to represent the ground-water storage plus sediment storage.

In general under present conditions and with the rough estimates now available for evaporation, precipitation, and unmeasured inflow, the annual change in gross storage averages about 12 percent more than the change in reservoir contents indicated by the capacity table. At the spillway level of 1,221.4 feet, the computed gross capacity of Lake Mead is about $35,000,000$ acre-feet, or 3, 750, 000 acre-feet more than is indicated by the capacity of the table. The sediment particles carried into the reservoir between 1935 and 1948 have a total estimated volume of 550,000 acre-feet, and the water storage beneath the reservoir sides and bottom when the lake is filled to capacity is therefore about $3,200,000$ acre-feet.

Under present conditions there is a considerable variation in usable ground-water storage with change in lake levels, which adds materially to the degree of river regulation afforded by the reservoir. From September 1941 to September 1946 there was a net decline of 52.2 feet in reservoir level.. Reservoir contents declined 7, 140, 000 acre-feet, but the gross storage contributing to the discharge at Hoover Dam amounted to $7,800,000$ acre-feet, indicating a recovery of $660,00 \mathrm{C}$ acre-feet from ground-water storage during this 5-year drawdown. Because of the time required for water to saturate or drain from porous material, it is likely that the ground-water storage changes only slightly during short-time or seasonal changes in reservoir level.

\section{LIMNOLOGY}

This study is concerned especially with the physical and chemical characteristics of the lake water, and with interpretations and conclusions based on those characteristics. In part, these characteristics are products of the environment of the lake: the hot and dry climate; the reservoir bed of ridges, canyons, and broad basins; and the soluble rocks that form the reservoir floor in some places. In large part, however, these physical and chemical characteristics are inherited from the water that flows into the lake. A knowledge of the characteristics of the inflowing water is therefore prerequisite to an understanding of the characteristics of the lake water. Accordingly, there follows first a discussion of the physical and chemical characteristics of the inflow and second sections describing the chemical and physical limnology of the reservoir.

\section{Physical and Chemical Characteristics of the Inflowing} Water, by C. S. Howard

About 95 percent of the inflow to Lake Mead comes from the Colorado River and is measured at the Grand Canyon gaging station, 190 miles above the uppermost basin (Pierce Basin) of the lake. The inflow from side canyons and tributaries below Grand Canyon, including the Virgin River, is probably not in sufficient volume to have any significant effect on the physical and chemical characteristics of the water in Lake Mead.

In the first 14 years after the beginning of storage in Lake Mead, 1, 995 million tons of suspended sediment passed the Grand Canyon station. Thus the Colorado River has carried sediment toward Lake Mead at an average rate of 142 million tons a year. Since 1926 the annual suspended load measured at the Grand Canyon station has varied from about 50 million tons in 1934, when annual runoff was less than 5 million acre-feet, to nearly 500 million tons in 1929 , when annual runoff was more than 19 million acre-feet. Plotting of the annual runoff against sediment load (fig. 5) shows that the sediment load is not directly proportional to the runoff, but increases more rapidly with increasing discharge. In the years 1941-50 the sediment load has generally been less at equivalent runoff then in the preceding 15 years. The concentrations and sediment loads of the inflow during the 1948-49 survey were near the average for the period since 1935 at Grand Canyon.

In the winter months, November to March, the river discharge is usually near the minimum for the year, ranging from 3,000 to $10,000 \mathrm{cfs}$. Sand particles rarely comprise more than 10 percent of the suspended load, and clay is likely to make up half or more of the total. During the period of greatest volume of flowApril to July-sand ordinarily constitutes at least 20 percent and may be more than 50 percent of the sediment load. From August to October the discharge of 


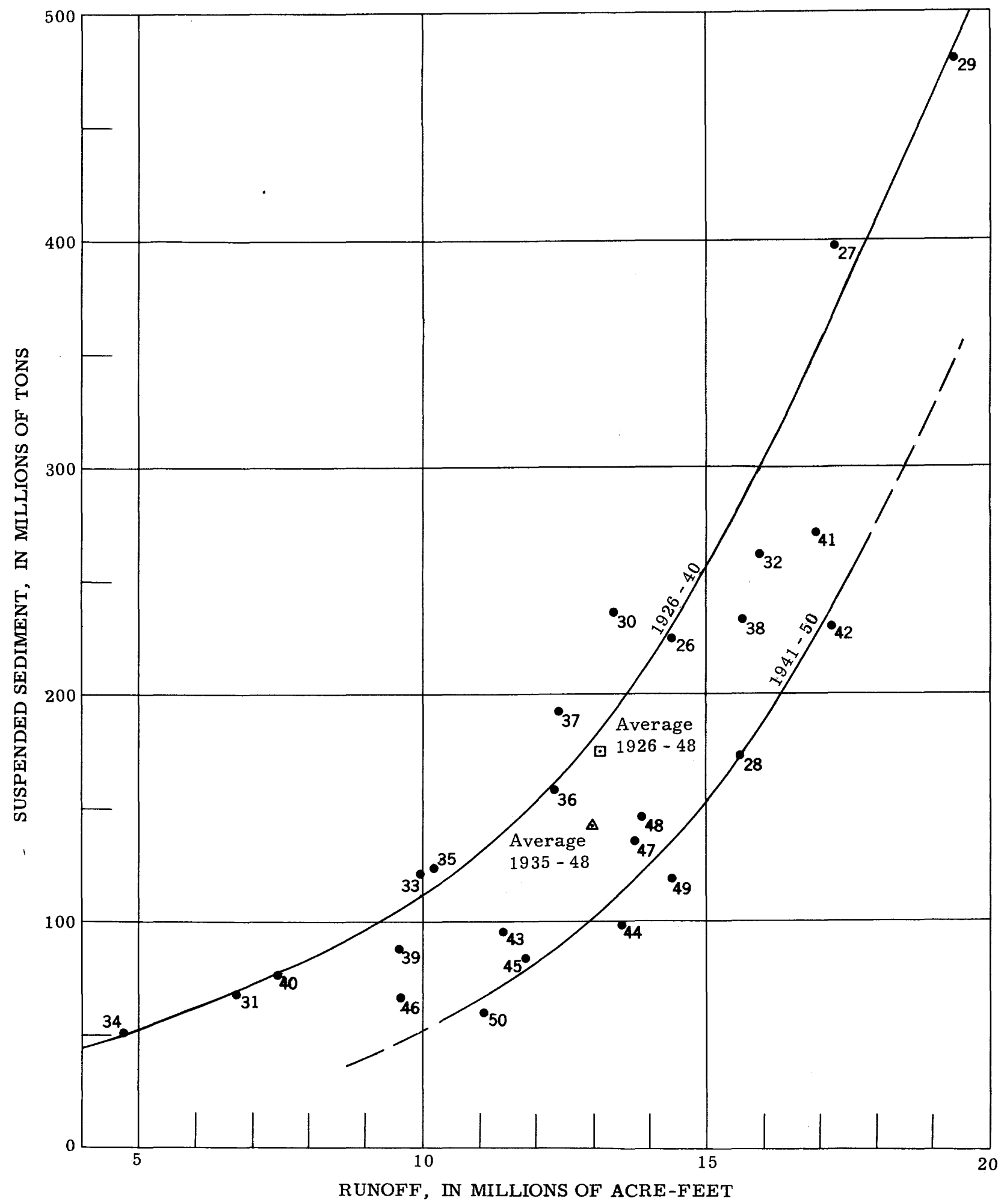

Figure 5. - Relation of annual runoff to sediment load at Grand Canyon. 
PERIODS OF DENSITY CURRENTS

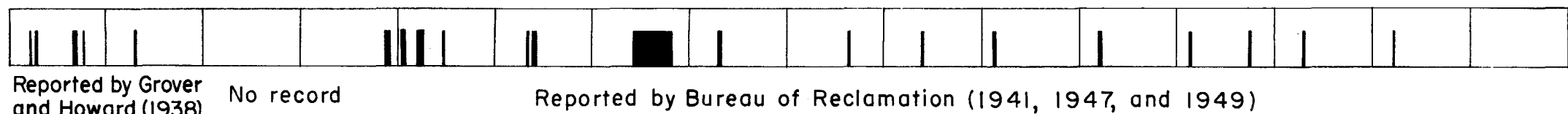

Reported by Bureau of Reclamation (1941, 1947, and 1949)

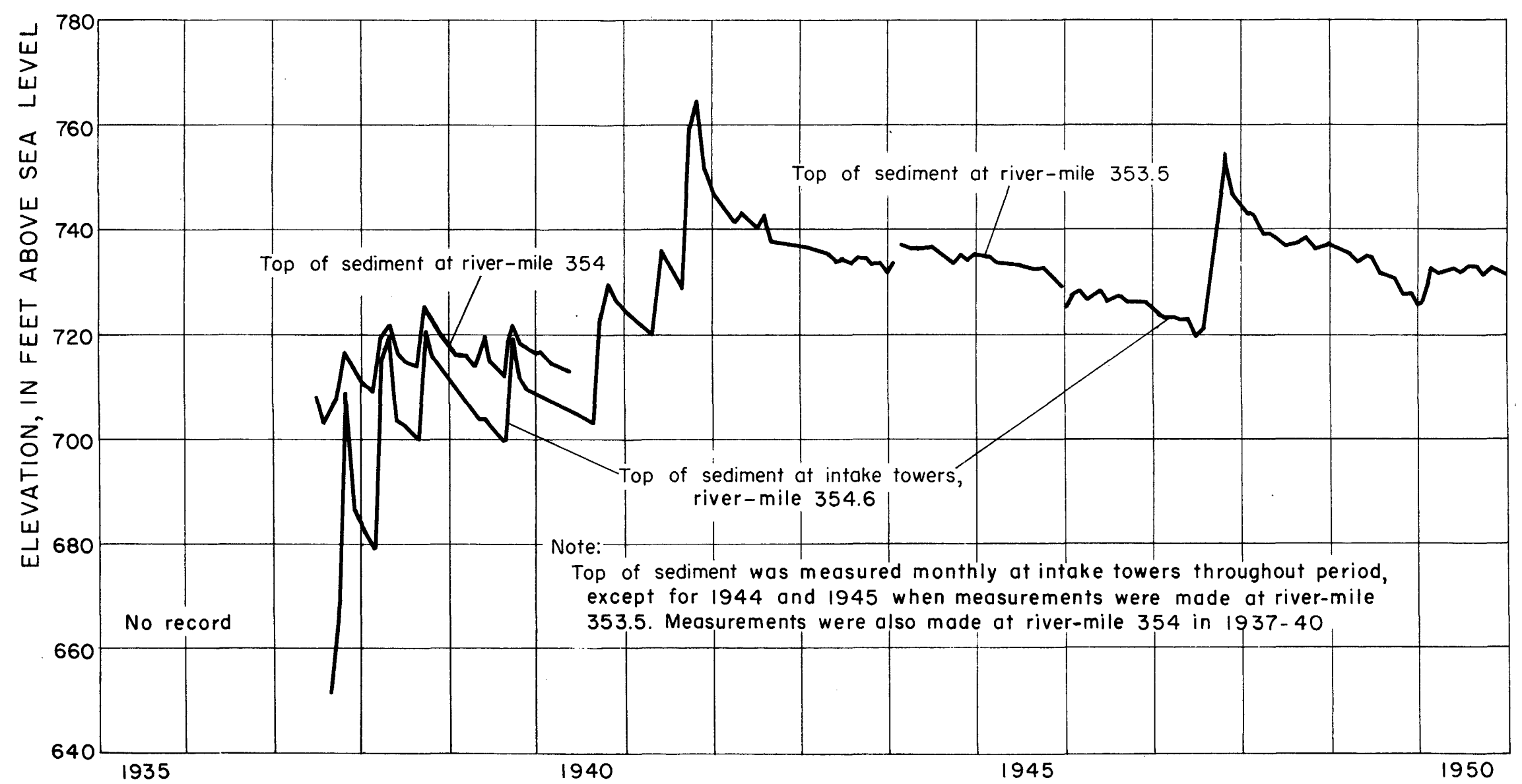

Figure 6. --Periods of reported density currents and elevation of top of sediment near Hoover Dam, $1935-50$. 
the river may drop to less than $5,000 \mathrm{cfs}$, or it may increase to $30,000 \mathrm{cfs}$ or more for short periods because of flood runoff from cloudburst storms. Regardless of the discharge the distribution of particle sizes in the suspended load is generally similar to that in the winter, with less than 20 percent sand, and a predominance of clay and very fine silt.

Most of the dissolved mineral matter in Lake Mead is carried in by the Colorado River. The river has the lowest concentration of dissolved solids in the spring during the period of flood stages resulting from melting. snow, and the maximum concentration is found during the periods of low flow when the runoff consists almost entirely of ground-water inflow. The concentration of dissolved solids may also be relatively high during floods which come after heavy rains on the arid portions of the drainage area. During the 1948-49 survey, the dissolved solids ranged from 800 to 1,000 parts per million (ppm) in early 1948, decreased to a minimum of $276 \mathrm{ppm}$ in the period June $11-20$, rose to 1,380 ppm October 11-20, and then fluctuated between 800 and $1,200 \mathrm{ppm}$ during the winter of $1948-49$. These variations were less than have been recorded in some years since 1935. In 1942 the dissolved solids reached a 10-day minimum of $225 \mathrm{ppm}$ on June 11-20, and a maximum of $1,350 \mathrm{ppm}$ on September 21-30. In 1940 the range was even greater, from a minimum of 334 ppm in the 10-day period June 1-10 to a maximum $1,720 \mathrm{ppm}$ on September 1-10. The maximum 10-day average concentration in the period of record was $1,890 \mathrm{ppm}$ on September 21-30, 1934, before Hoover Dam was completed.

The average annual concentration of dissolved solids in the Colorado River has varied from $491 \mathrm{ppm}$ in water year 1928 to $960 \mathrm{ppm}$ in 1934. Since Hoover Dam was completed in 1935 the weighted average concentration of dissolved solids at Grand Canyon ranged from $749 \mathrm{ppm}$ in calendar year 1940, the year of minimum runoff, to $505 \mathrm{ppm}$ in 1942, following the year of greatest runoff. This weighted average concentration has varied greatly from year to year; it decreased about 25 percent from 1940 to 1941 , and increased by an even larger percentage from 1938 to 1939 .

\section{Density Currents, by C. S. Howard}

A density current has been defined as a gravity flow of a fluid through, under, or over a fluid of approximately equal density (Bell, 1942b). Apparently this flow takes place with very little mixing of the two fluids. For the density currents in Lake Mead, the difference in density may result from differences in temperature or in content of dissolved material or suspended material, or a combination of these three factors. Generally the difference in density has been caused partly by particles in suspension, so that the water in the density current is turbid (p. 20).

The water stored in the lake forms the medium in which density currents can flow; the causative factor is the inflowing water, because of its different density, which in turn is dependent upon its suspended load, dissolved solids, and temperature. Thus the characteristics of the inflow are the characteristics which under favorable conditions produce density currents in the lake.
The first and still the best evidence of density currents flowing through the entire length of Lake Mead was obtained during the first 15 months of operation of Hoover Dam (Grover and Howard, 1938). Subsequently, laboratory studies of density currents were made by the Soil Conservation Service (Bell 1942a, b). The Bureau of Reclamation and the Geological Survey made field observations of density currents in Lake Mead, which have been reported by the Bureau of Reclamation (U. S. Dept. Interior, 1941, 1947, 1949, 1953). During the Lake Mead survey the observational and samplecollecting program was expanded, with considerable emphasis being given to the collection of data in the upper end of the reservoir.

Density currents have been reported in each year since 1938, and in all months except January. Some of these density currents occurred during or immediately prior to recorded increases in the amount of sediment at the face of the dam, but others are not clearly related to such increases. Since August 1937 the sediment level has risen more than 15 feet in each of eight periods; the amount of rise was more than 35 feet in the fall of 1941, and almost as much in the fall of 1947 (fig. 6). Following each of these eight major rises the sediment level has declined, rapidly at first and then more gradually, presumably owing in part to compaction. Several minor rises or interruptions in this general downward trend may indicate minor accretions of sediment at the dam. It is possible also that there is some redistribution of sediment in the Boulder Basin subsequent to deposition by density currents.

\section{Chemical Limnology, by C. S. Howard}

During the late winter the concentration of dissolved solids in the lake water is fairly uniform throughout the lake, both in depth and areal distribution. In March 1948 there was less than 30 percent variation in the concentration of dissolved solids from Pierce Ferry to the intake towers and at practically all depths.

The freshets of April to July bring in water of lower concentration than the lake water. As a result the surficial water is more dilute than the deeper water in parts of the upper lake, and water with a dissolvedsolids concentration as low as $300 \mathrm{ppm}$ is found as far down lake as Gregg Basin in late May and the eastern part of Virgin Basin in late July. In the Boulder Basin the concentration of dissolved solids in surficial water never reaches the minimum observed in the eastern part of the lake, showing that some mixing and probably some increase in solids through evaporation and solution have taken place. On the other hand, by late summer the surficial water at the head of the lake is more concentrated than that in the Boulder Basin.

Inflow from the Colorado River and evaporation losses from the lake are least in November, December, and January. As the air temperature lowers, the surface water cools, becomes more dense, and moves to greater depth in the lake. This causes a mixing of the water of the upper layers, and monthly samples during the survey of 1948-49 show a mixing to progressively greater depths. The extent of the mixing in any season depends upon the extreme air temperatures reached. In January 1949 the mixing extended the en- 
tire depth at the intake towers, but in 1943 only the upper 150 to 200 feet of the lake was affected. By the close of the winter season, just before the spring inflow, the lake water is as thoroughly mixed as it can be for the year.

Throughout the year, except during a short period in late winter or early spring, there is definite stratification of the lake water, as shown by the existence of two or more layers of water at different concentrations. At the bottom of the lake the dissolved solids, alkalinity, and temperature of the water are higher than in the main body of water. Usually samples of this water have large quantities of sediment. The greater dissolved-solids content is mostly in calcium and bicarbonate, and it is likely that these constituents have been dissolved from the sediment. Prolonged contact of water with the sediments produces a further increase in alkalinity and dissolved solids. Samples collected at the intake towers and stored in the laboratory increased $50 \mathrm{ppm}$ in alkalinity in a 2 -month period and $178 \mathrm{ppm}$ in a year.

The temperatures of water recorded at the surface in the main body of the lake have ranged from $53^{\circ}$ to $90^{\circ} \mathrm{F}$. These surface temperatures are affected by wave action, wind currents, and evaporation, but the trends reflect the changes in atmospheric temperature. Large diurnal and seasonal fluctuations occur only in the surficial zone of the reservoir. Water in the main part of the lake and at most depths has a fairly uniform temperature of about $52^{\circ} \mathrm{F}$. At the intake towers the range in temperature at depths greater than 150 feet (except at the bottom) is less than $4^{\circ} \mathrm{F}$. The temperature of the water throughout the lake approaches uniformity in the winter both in depth and geographic distribution.

Analyses of water released from the reservoir show a variation generally less than $100 \mathrm{ppm}$ of dissolved solids in the course of a single year. This variation is very small in comparison with that of the inflowing water, which commonly varies by more than $1,000 \mathrm{ppm}$ of dissolved solids during a year. Thus it is evident that there is a great amount of mixing of waters in Lake Mead (p. 15).

Changes within the lake result in changes in content of dissolved solids in the stored water. The white precipitates along the shores below the high-water line of the reservoir are conspicuous, although they represent a very small volume of material. The disappearance of soluble rock materials from the bed or banks of the reservoir has also been noted in some places. Finally, significant quantities of water have been lost from the reservoir by evaporation, with a resultant increase in concentration of dissolved solids in the water remaining in the reservoir. The effects of these chemical phenomena within the reservoir are shown by comparison of the analyses of the inflowing and the outflowing water.

The dissolved solids carried past the Grand Canyon station, based on annual weighted average analyses, has ranged from 6,100,000 tons in the water year 1934 (a year of serious drought) to $12,900,000$ tons in 1941 . In the water year 1934 the dissolved solids in the river below Hoover Dam amounted to 6,500,000 tons, slightly greater than that measured at Grand Canyon. A total of $140,000,000$ tons was carried by the river in the
14 water years $1935-48$, and it is estimated that an additional $8,000,000$ tons was carred in the unmeasured inflow to Lake Mead in this period. In the 14 years the dissolved solids in the outflowing water totaled $136,000,000$ tons, or about $12,000,000$ tons less than that carried in the inflow.

Since April 1, 1936, the dissolved solids in the outflow have never exceeded $825 \mathrm{ppm}$, whereas the concentration of dissolved solids in the inflow has for short periods exceeded $1,700 \mathrm{ppm}$. On the other hand, the sulfate concentration in the outflowing water in every year from 1937 through 1949 has been greater than in the inflowing water and in several years has been more than 50 percent greater. The calcium content of the outflowing water has been generally 20 to 35 percent greater than that of the inflow, and the sodium content in the outflowing water has also been as much as 25 percent greater in several years. These changes within the reservoir are correlative with the solution and precipitation of mineral matter by the lake water and with the overall concentration resulting from evaporation.

The evaporation losses from Lake Mead are about 5 to 7 percent of the average inflow to the lake, or about 700,000 to 900,000 acre-feet a year. The soluble salts from the evaporated water are left in the lake, thereby increasing the concentration of dissolved solids in the lake water.

It is estimated that during the first 14 years of storage more than $1,000,000$ tons of silica and $9,000,000$ tons of calcium carbonate have been precipitated in the lake. Most of the white deposit above the waterline and around the lake edge is calcium and presumably carbonate, probably deposited by precipitation following loss of carbon dioxide. Silica comprises about $20 \mathrm{per}$ cent of the material. The marked decreases in silica and bicarbonate shown in the weighted average analyses of the outflowing water constitute additional evidence of precipitation from the lake water.

The water released from Lake Mead has shown in almost every year a higher concentration of dissolved solids than the average for the inflow. Assuming that the 24,600, 000 acre-feet of water in Lake Mead on September 30,1948 , carried 0.91 ton of dissolved solids per acre-foot, the total solids in the lake would be about $22,300,000$ tons, of which about $12,000,000$ tons is accounted for by the 14 -year cumulative difference between inflow and outflow. The increase of more than $10,000,000$ tons represents only part of the dissolving action within the lake during the first 14 years of storage, because an estimated 10,000,000 tons of calcium carbonate and silica have been precipitated from the stored water. The total increase, about $20,000,000$ tons, has been chiefly calcium and sulfate, derived from gypsum and anhydrite forming the lake bottom and shores.

Although there has been an increase in dissolved solids through evaporation and solution, there has also been a stabilization of the chemical quality during the period of storage which has been of considerable value to the users of water below Hoover Dam. As a result of that stabilization a lower tonnage of soluble salts has been delivered to the irrigated lands below Hoover Dam than would have been delivered if there had been no storage. This is because the concentration of soluble salts in the unregulated river water (as indicated 
by the Grand Canyon records) is higher than the concentration in the released water during the periods when most of the water is taken from the river for irrigation. Thus the "alkali" problem of the lands irrigated by the Colorado River below Lake Mead has been decreased to an appreciable extent.

\section{$\frac{\text { Physical Limnology, by E. R. Anderson and }}{\text { D. W. Pritchard }}$}

The Navy Electronics Laboratory's objectives in the Lake Mead survey were: 1) To determine the general circulation of the lake from the distribution of temperature and salinity, and 2) to establish a preliminary energy budget from which an estimate of evaporation could be made. These authors have published (1951) a detailed description of the methods and techniques employed, a complete analysis of the data with respect to circulation and evaporation, and a summary of the basic data taken on the various limnological cruises. The technical report of the comprehensive survey contains only a summary of these studies.

Oceanographic techniques were utilized to establish the general features of the circulation in Lake Mead. Analysis of the data collected during 12 monthly cruises on Lake Mead indicates a distinct and orderly cyclic progression in distribution of properties and in the implied circulation which can be related to the seasonal changes of weather and river inflow.

In the winter the salinities in the lake are uniform, ranging from 600 to $700 \mathrm{ppm}$ (fig. 7). The inflowing denser Colorado River water flows along the lake bottom, appearing to influence bottom salinities well into Boulder Basin. A single cellular circulation exists, resulting in an uplake flow of surface waters from Virgin Basin.

The spring runoff results in high inflow from Colorado River which, because of its low salinity of 200 to $300 \mathrm{ppm}$, flows out over the lake water, producing a layer of low salinity over most of the lake. The flow along the surface sets up a cellular circulation below 150 feet which gives rise to flow uplake along the bottom.

In summer, with decreasing inflow and increasing salinity of inflow, the downlake spread of Colorado River water occurs below the surface at about 80 feet. Two distinct cellular circulations occur above Virgin Canyon, one in the surface flow and the other below 80 feet, resulting in an uplake flow in deeper waters. There is some evidence of a third cell, producing downlake flow along the bottom, being caused by the sinking of some sediment-laden inflow water along the bottom.

In the fall the decrease in temperature of inflow from Colorado River is associated with a greater sinking of the inflowing river water. During this season there is downlake flow along the bottom until, at about 170 feet in depth, the flow spreads horizontally downlake and then slopes up slowly toward the surface. Two large cellular circulations, one producing uplake movement of surface water and the other uplake movement of bottom water exist above the Virgin Basin.
The seasonal cycle is completed when, with further increase in density, the inflowing water flows all the way down the slope of the delta along the bottom. The deep cellular circulation is eliminated and the single cell of the winter season remains.

Overton Arm appears to reflect primarily the water conditions found in Virgin Basin. The influence of flow from Virgin River is seen only in the upper few miles of the arm. Sedimentation below Lower Narrows in Overton Arm appears to result from the flow into Overton Arm of water of Colorado River origin. Turbid water from this source was observed to extend into Overton Arm during the May survey. Characteristic of all seasons is the relative uniform character of the Boulder Basin, indicating that the Virgin Basin acts as a sort of large "mixing bowl," in and above which the large seasonal variations in salinity of the inflowing waters are smoothed to nearly their mean value.

That conditions differ from year to year is evident from the differences found between February 1948 and the same month of 1949 , which was abnormally cold. The temperature of inflow in February 1949 was some $8^{\circ} \mathrm{F}$ less than in 1948 , and the temperatures in the lake ran from $3^{\circ}$ to $5^{\circ}$ less at all levels. The inflow during February 1949 was only 4,500 cfs as compared with $13,000 \mathrm{cfs}$ a year earlier. Despite these differences the major character of the salinity pattern and the indicated circulation did not differ materially between the two winter seasons. It is believed that the important features of the circulation for all seasons as presented above is repeated from year to year.

In their estimate of evaporation from Lake Mead, Anderson and Pritchard stress the preliminary nature of their energy budget. Since the completion of the comprehensive survey of Lake Mead the Geological Survey, Navy Electronics Laboratory, Bureau of Reclamation, and Weather Bureau have cooperated in further research in this field at Lake Mead and elsewhere, with the result that data are now being collected which permit determination of evaporation from Lake Mead with a high degree of accuracy. The basic pattern of the energy budget as outlined by Anderson and Pritchard still holds, but their estimates of certain parameters in this budget, particularly solar radiation and longwave radiation, would be modified by the subsequent refinements and instrumentation.

\section{SEDIMENTOLOGY}

\section{Methods of Investigation, by H. R. Gould}

The conclusions concerning the accumulated sediment are based largely on studies of more than 1,800 samples, of which about 1,500 were 6 - to 12 -inch segments of 46 cores, and the others were collected by Foerst sampler, dipper, snapper sampler, or pick. Of the cores, 38 were obtained by a gravity corer, which penetrated to a maximum depth of 95 feet, with an average recovery of 35 percent. A piston corer used at 8 other locations penetrated to a maximum depth of 79 feet, with recovery generally close to 100 percent (Smith, W. O., report in preparation). Physical properties of the sediments were measured by standary laboratory procedures. Sherman $(1951,1953)$ describes some of 

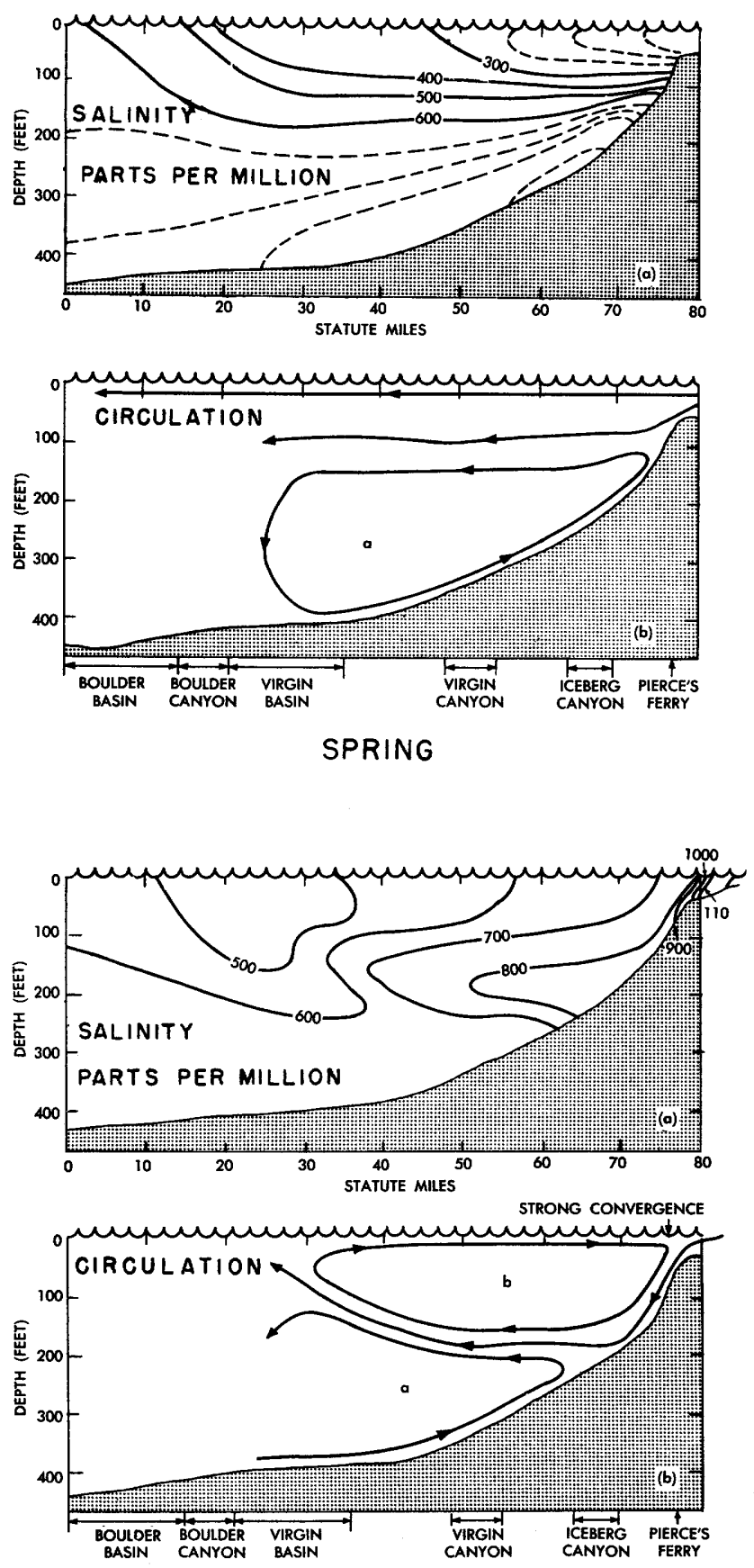

AU TUMN

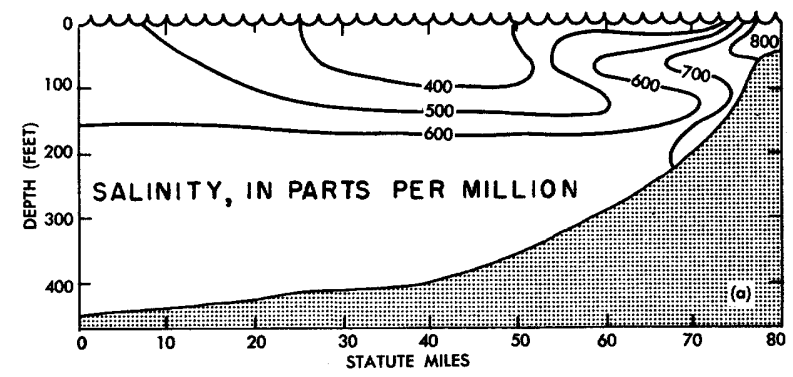

WEAK TO MODERATE CONVERGENCE
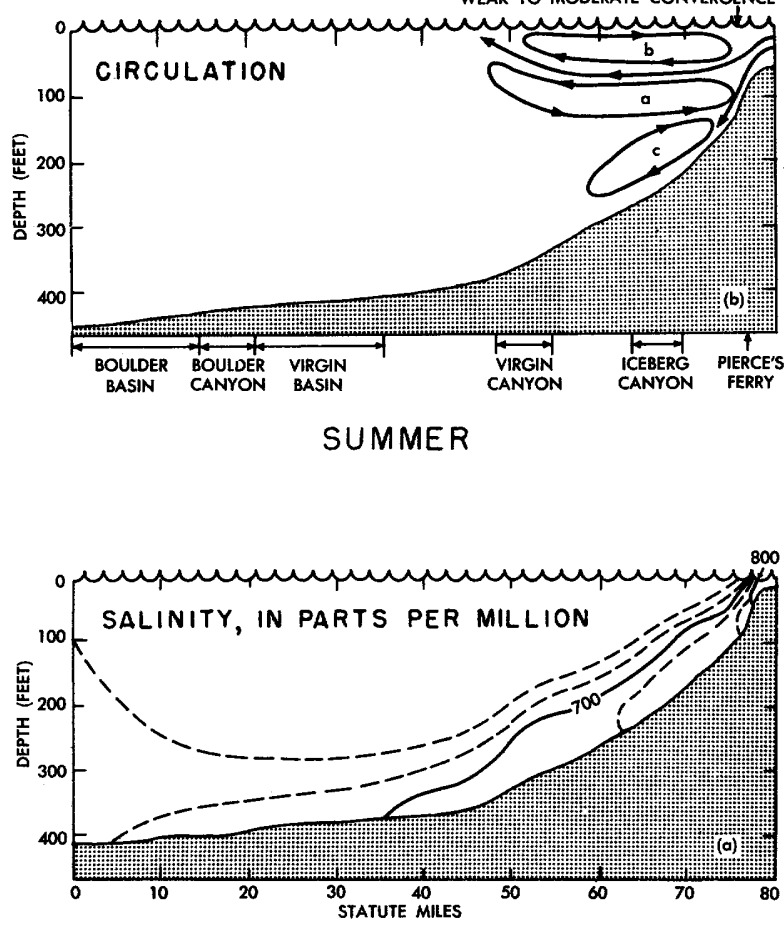

STRONG CONVERGENCE

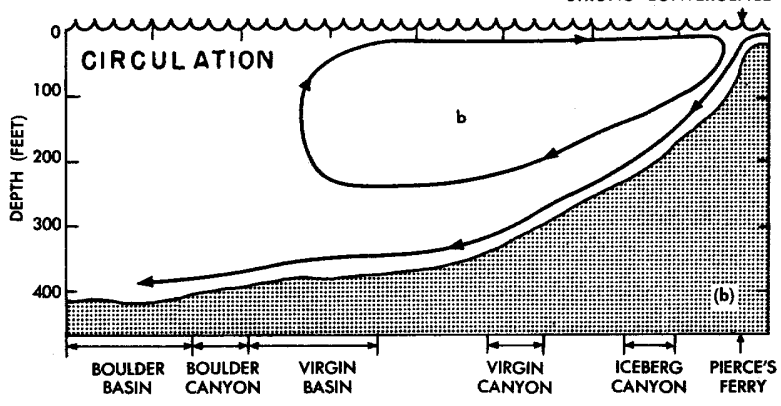

WINTER 
these procedures in his discussions of textural analyses and of the flocculent structure of sediments in Lake Mead.

\section{Characteristics of the Accumulated Sediment, by \\ H. R. Gould}

The sediment accumulated in Lake Mead has formed two deltas, one of which extends from Bridge Canyon to Hoover Dam along the thalweg of the Colorado River, and another of much smaller size along the inundated Virgin River channel. Most of the sediment brought into Lake Mead is supplied by the Colorado River and accumulates in the Colorado delta.

Deltas are characteristically formed by sedimentladen streams where they enter the ocean or other bodies of still water. The growth of the delta may be analyzed conveniently with reference to the point at which the flowing water meets the still water: Sediment is dropped in the river bed as water velocities are reduced; additional sediment is carried to the edge of this graded slope and dropped into the deeper stillwater body to form foreset beds; finer material is carried farther out into the still-water body and there forms the bottomset beds. As deposition continues the foreset beds are built out progressively farther over the bottomset beds, and in turn are covered by topset beds; also the gradient of the stream is modified and sediment is deposited upstream from the original mouth. Thus the delta grows outward in the still-water body, by deposition of foreset and bottomset beds; by the deposition of topset beds it grows upward, and it also projects backward into the original channel of the stream that provides the source material.

The Lower Granite Gorge and the eastern part of Pierce Basin have been filled with sediment to a level higher than the average lake level (approximately 1, 170 feet altitude). The Colorado delta progressively increases in thickness from Bridge Canyon to Pierce Basin, where it attains a maximum thickness of 270 feet. Topset beds make up the surface of this part of the delta. Although some of the topset beds in the Low er Granite Gorge are above the level of the permanent spillway crest $(1,205.4$ feet altitude), the delta in its present stage of development does not extend upstream from the original eastern end of the reservoir.

West of Pierce Basin the delta lies entirely beneath the average lake surface, and is confined to the region of the submerged Colorado River channel. Foreset beds make up the surface of the delta in part of Pierce Basin, but from that basin to Hoover Dam, a distance of about 75 river-miles, the delta surface is composed of bottomset beds. In Iceberg, Virgin, Boulder, and Black Canyons steep walls bound the sediment on either side, but in the intervening basins the delta spreads out over the terraces that flank the inundated Colorado River channel.

The topset beds that make up the surface of the Colorado delta in the Lower Granite Gorge have an average slope of 1.2 to 1.3 feet per mile, over which the Colorado River flows into Pierce Basin. Because of extreme fluctuations in river discharge and changes in lake level, the topset beds are reworked extensive ly, but observations during 1948 and 1949 show that the average gradient of 1.25 feet per mile is virtually unchanged throughout the year.
The foreset beds that make up the delta front in Pierce Basin dip sharply beneath the lake surface for a distance of about $1 \frac{1}{2}$ miles, measured along the course of the submerged Colorado River channel. Near its southern margin the delta front ranges in slope from about 300 feet per mile near the top to less than 25 feet per mile near the foot, and averages about 100 feet per mile. The central and northern part of the delta front is traversed by a valley 300 to 1,000 feet wide, and as much as 25 feet below the average delta front. The axis of this valley extends toward the mouth of the Colorado River. At the foot of the delta front the valley broadens out onto the gently sloping surface of the bottomset beds. The average slope of the delta front measured along the valley axis is about 55 feet per mile.

From the foot of the delta front to Hoover Dam, the average slope of the bottomset beds is about 4 feet per mile, ranging from an average of 9 feet per mile between the delta front and the mouth of Iceberg Canyon to less than 1 foot per mile in the southern part of Boulder Basin. There is a marked reduction in slope of the bottomset beds beginning in the vicinity of Virgin Canyon and extending westward to the dam. The bottomset beds in 1948 had a minimum thickness of 45 feet in the Temple Bar area, increasing progressively to 106 feet at the dam.

The Virgin delta occupies only the upper 14 miles of the Overton Arm, and there it is restricted chiefly to the inundated channel and flood plain of the Virgin River. Except for their subdued relief, the surface features of the Virgin delta are generally similar to those of the Colorado delta. The topset beds make up the surface of the upper 8 miles of the Virgin delta, and they have an average slope of 10.7 feet per mile. A break in slope at altitude 1,140 feet marks the delta front, where the topset beds grade into the foreset beds, which have an average downstream slope of 29 feet per mile. Farther south the delta is composed of bottomset beds with an average slope of 14 feet per mile, which grade into the profile of the former Virgin River channel at the toe of the delta.

The growth of deltas in Lake Mead is necessarily more complex than those of streams debouching into an ocean or into a lake having relatively constant level. During the first $6 \frac{1}{2}$ years of the lake history the point at which the river entered still water migrated from the Boulder Basin to Bridge Canyon in the Lower Granite Gorge (a distance of more than a hundred rivermiles), with variations each year corresponding to the fluctuations in lake stage. Since July 1941 the lake has generally been at elevations ranging from 1,150 to 1,200 feet, reaching a minimum level of 1,134 feet in April 1947, and the river has entered the lake either in Pierce Basin or in the western part of the Lower Granite Gorge. A general idea of the growth of the Colorado delta from 1937 to 1948 may be obtained from the profiles of plate 1 .

The Lake Mead deltas are made up almost entirely of particles of sand, silt, and clay. Gravel is present only in the easternmost 2 miles of the reservoir and is confined to the center of the channel; only a very small part of the detrital load carried into the lake by the Colorado River is composed of gravel. The sand has been deposited at or near the mouths of the Colorado and Virgin Rivers and is confined, therefore, to the topset and foreset beds of the deltas. On the other 
hand, the silt and clay particles have been carried into the deeper parts of the lake and deposited in the bottomset beds. As a result, the Lake Mead deltas are geographically graded, the coarsest particles accumulating at the heads of the deltas and the finest particles at the greatest distance from the source. This gradation in particle size has produced a gradational change in most other physical properties of the deltas. For example, the sand of the topset and foreset beds, because of its small volume of interstitial water, is hard and firmly packed, but the silt and clay of the bottomset beds have an extremely high water content which has given them the consistency of a soft ooze. Only samples of the most deeply buried layers are solid enough that they do not flow under their own weight. There are numerous gas cavities which in some zones give the bottomset beds a spongelike appearance.

The water content and porosity are of particular interest since they provide the best indication of the amount of compaction that has taken place in the accumulated sediment. When the silt and clay of the bottomset beds are deposited, the water content is commonly more than 80 percent of the wet weight of the accumulated sediment, and the porosity exceeds 90 percent. As additional layers are deposited on top of those in place, the solid particles of the buried material pack together more tightly, thus driving out part of the water. The water content and porosity of the accumulated sediment are also related to the size, shape, and.sorting of the particles. The relationship is well illustrated in the Colorado delta where the water content ranges from 16 percent in the sand of the topset beds to 75 percent in the silt and clay of the bottomset beds. Expressed in terms of volume, the porosity ranges from 34 percent to 89 percent. The water content in all sections decreases with increasing depth.

Sand and gravel when they are first deposited have a high specific weight because of the dense packing of the constituent particles. Silt and clay have a very low specific weight when they are initially laid down because of the loose arrangement of the solid grains. In the Colorado delta the specific weight ranges from 108 pounds per cubic foot for coarse sand to as little as 18 pounds per cubic foot for silt and clay (fig. 8).

According to laboratory experiments by Terzaghi (1925), the consolidation or increase in specific weight of sand is insignificant when subjected to pressures less than about 100 pounds per square inch. Since the weight of the superimposed load reaches this value only in the most deeply buried sand layers east of the delta front, the specific weight of the topset and foreset beds probably does not increase appreciably with increasing depth, and the specific weight of the surface material is characteristic of all depths. Consequently, the specific weight of all the sand in the topset and foreset beds east of the delta front is estimated at 93.8 pounds per cubic foot, which is the average specific weight of 12 samples collected from the surface of the topset and foreset beds.

It has been assumed that the deeply buried bottomset beds east of the Colorado delta front are similar in texture to the bottomset beds immediately west of the delta front. Data from the bottomset beds immediately west of the delta front are available, however, only to a sediment depth of 95 feet. Extrapolation of these data to greater depths gives an estimated mean specific weight of 100 pounds per cubic foot for the deeply buried bottomset beds in the vicinity of the delta front.

It is estimated that the Colorado delta has an average calcium carbonate content of 10.3 percent. This quantity is far greater than can be accounted for by precipitation from the lake, and it is concluded that large quantities of calcium carbonate are carried into the lake as part of the suspended load of the Colorado River. This conclusion is confirmed by analyses by Sykes (1937) of the suspended load of the Colorado River deposited in the delta at the head of the Gulf of California, which indicate that the suspended load has an average calcium carbonate content of 10 percent.

The average organic content of samples from the bottomset beds is 0.93 percent, and of samples from the topset and foreset beds, 0.14 percent. Within the bottomset beds the organic content shows a general but somewhat irregular decrease from 1.12 percent in Pierce Basin to 0.68 percent at Hoover Dam.

\section{Bacteriology and Biochemistry of the Sediments, by F. D. Sisler}

Bacteriological examinations were made of samples of the sediment midway between the intake towers at Hoover Dam. The samples were collected from depths of $0.3,46$, and 99 feet below the sediment surface, or approximately the top, middle, and bottom of the accumulated sediment. The samples indicated a progressive decrease in water content with depth, from 71 percent at the top to 62 percent at the bottom, and an increase in temperature from $52^{\circ} \mathrm{F}$ at the top to $58.4^{\circ} \mathrm{F}$ at the bottom. The median particle diameter of a sample from 93-foot depth was 0.0006 millimeter and 97 percent of the particles were smaller than 0.008 millimeter.

The total bacterial population was found to exceed $1,000,000$ bacteria per gram at all depths, and is thus comparable with raw sewage. Near the mud surface there is a minimum of $10,000,000$ bacteria per gram. By contrast the water within a foot above the sediment surface contained only 100 bacteria per gram. By comparison with marine and natural lake muds, the Lake Mead sediments are unique in containing a high bacterial population distributed uniformly throughout a deep and loosely packed layer.

Laboratory tests indicate that the abundance and activity of the microflora have contributed to the heating of the fresh sediment layer in Lake Mead, but radioactivity was found to be negligible as a possible source for the heating of the sediment in Lake Mead. It is estimated that the amount of heat from radioactivity is less than $10^{-10}$ calories per hour per gram, whereas the heat obtained from the biochemical oxidation of oxidizable material in Lake Mead mud is about $10^{-6}$ calories per hour per gram.

The evolution of methane from the mud was demonstrated in the laboratory. Methane production is a common occurrence in swamps and some lakes where conditions are anaerobic, and where abundant organic matter such as cellulose is present. Although the mud appeared to be a stable colloidal mixture, changing the reaction in the laboratory from $\mathrm{pH} 7.25$ to $\mathrm{pH} 10$ 


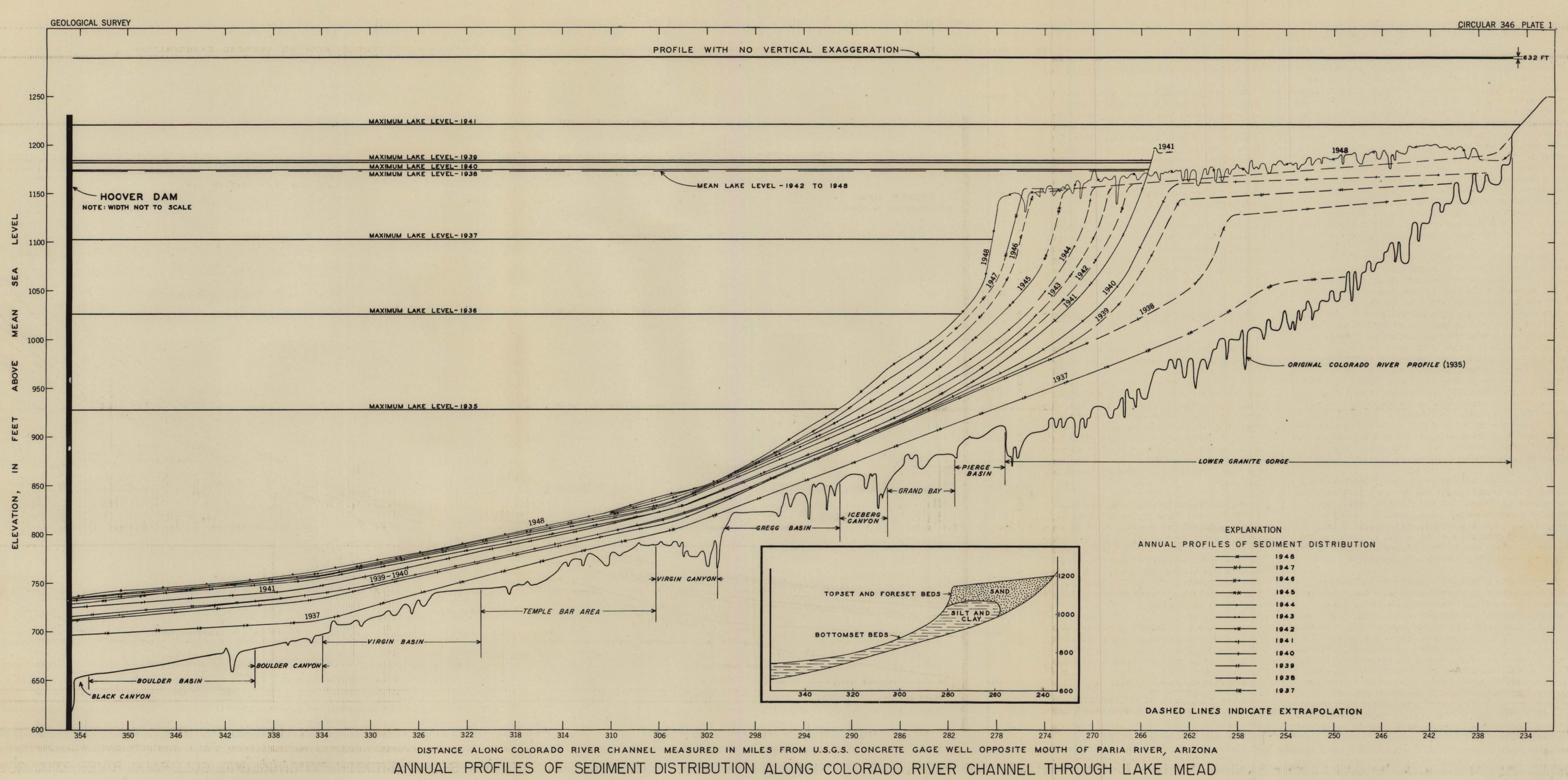




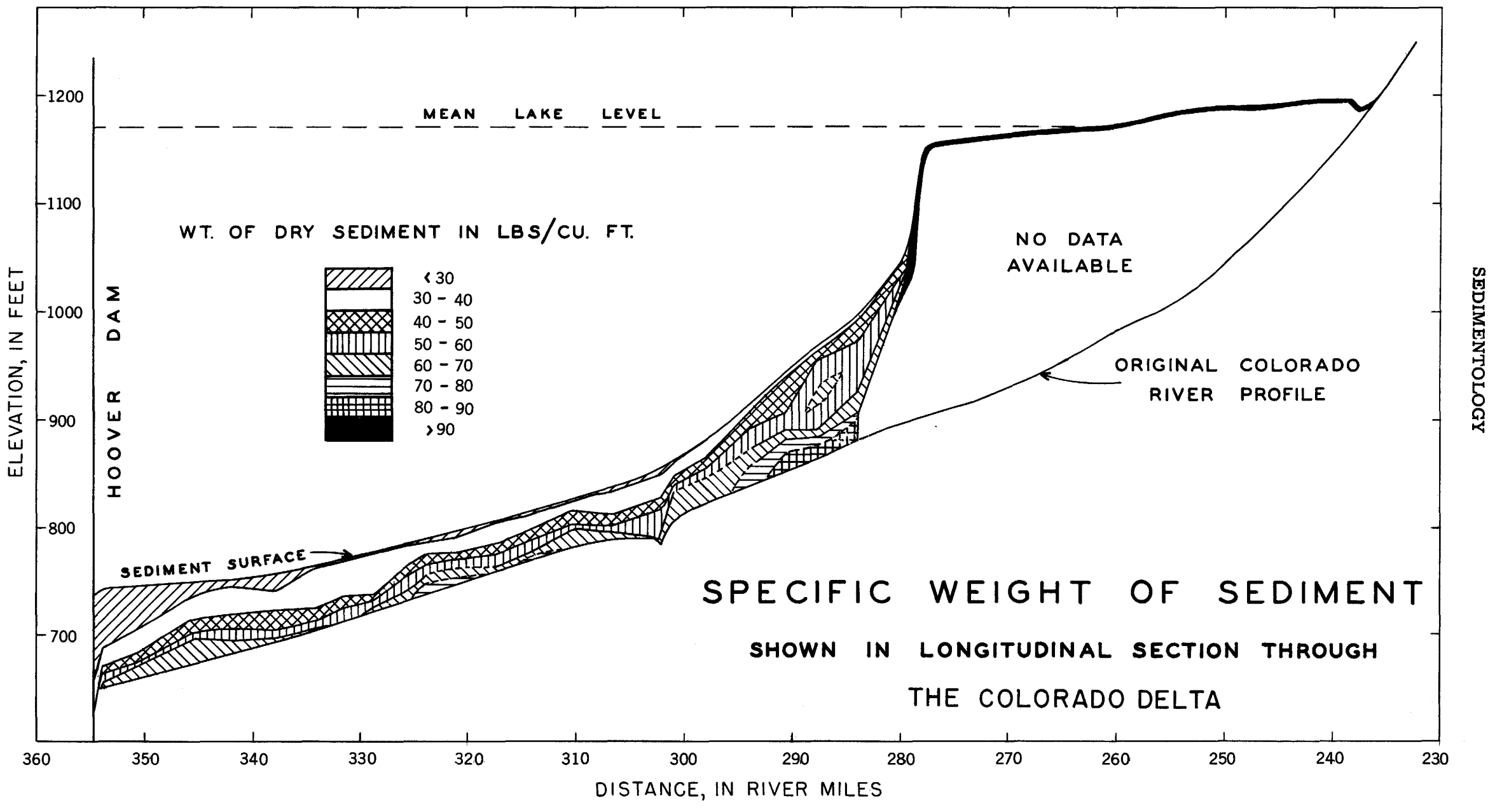

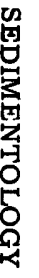


brought about a 22-percent volume reduction or compaction. The $\mathrm{pH}$ of sediments in situ may be a significant factor in compaction of those sediments.

\section{Amount of Sediment, by H. R. Gould}

The amount of sediment accumulated in Lake Mead may be expressed either in terms of volume--the space occupied by both the solid constituents and the interstitial water--or of weight, which includes only the solid particles. The weights, volumes, and certain other features of the sediment in individual basins of Lake Mead are summarized in table 2.

The average annual rate of sedimentation during the 14 -year period, $1935-1948$, is computed to be $144 \mathrm{mil}-$ lion tons. Most of the material in the Colorado delta and the Virgin delta has been supplied by the Colorado and Virgin Rivers, respectively. Consequently, the mean annual load of the Colorado River was 140 million tons, and that of the Virgin River only 4 million tons, in the 14-year period. During the same period the suspended sediment carried by the Colorado River averaged about 142 million tons a year or approximately 2 million tons more than the estimated average annual deposition of sediment from the Colorado River in Lake Mead in the same period. Such close agreement between the mean annual suspended load of the Colorado River and the average annual rate of sedimentation in the Colorado delta is striking.

Any material carried as bed load has not been included in the measurement of sediment passing the Grand Canyon station, whereas it is included in the es timate of the amount of sediment accumulated in the Colorado delta. If the quantity of sediment carried in the bed load were appreciable, the total amount of sediment in the Colorado delta should be somewhat greater than the total suspended load passing the Grand Canyon station. Since this is not the case, it appears that the bed load of the Colorado River is extremely small, and that practically all of the sediment supplied by the Colorado River is carried in suspension.
Transportation of Sediment by Turbidity Currents, by H. R. Gould

Some density currents (p.13) are produced solely by differences in temperature or salinity, whereas others may originate, at least in part, from differences in their amount of suspended sediment. The type of density current in which suspended sediment accounts for part of the difference in densilty is referred to here as a turbidity current. Some quantitative aspects of Lake Mead turbidity currents have been described elsewhere by Gould (1951).

A turbidity current may be rather simply defined as a gravity flow of turbid water through, under, or over water of different density. Part of the difference in density is produced by suspended sediment, but suspended sediment is not always the dominant factor. In the overflow type of turbidity current (Bell, 1942a) the lower density of the current is due to higher temperature or lower salinity or both. Similarly in the interflow or underflow type of current, suspended sediment may not account in some cases for as great a part of the higher density as does lower temperature or higher salinity. A density current moves through still water with very little mixing and remains identifiable because of the lack of mixing.

Turbidity currents are always present near the mouth of the Colorado River, but only rarely do they flow the entire length of the lake. The three types of currents designated above as overflow, interflow, and underflow all occur in Lake Mead. Overflows occur only during the late spring and early summer (usually from late April to early July) when the incoming river water is less saline than the water at the surface of the lake. Turbid overflows seldom extend west of the Virgin Basin and they apparently never reach the dam.

Interflows during 1948 were most prominent in August and September, when the temperatures of the river and the lake surface water were about the same, but the salinity of the incoming water was considerably greater than the salinity of the lake surface layer. The sus-

Table 2. --Sediment in individual basins of Lake Mead

\begin{tabular}{|c|c|c|c|c|c|c|c|}
\hline \multirow[b]{2}{*}{ Area } & \multirow[b]{2}{*}{$\begin{array}{l}\text { Percent } \\
\text { of total } \\
\text { area }\end{array}$} & \multicolumn{2}{|c|}{ Volume } & \multicolumn{2}{|c|}{ Weight } & \multirow[b]{2}{*}{$\begin{array}{c}\text { Mean specific } \\
\text { weight } \\
(\mathrm{lbs} / \mathrm{cu} \mathrm{ft})\end{array}$} & \multirow[b]{2}{*}{$\begin{array}{l}\text { Median } \\
\text { particle dia- } \\
\text { meter } \\
\text { (microns) }\end{array}$} \\
\hline & & Acre-feet & $\begin{array}{l}\text { Percent } \\
\text { of total }\end{array}$ & $\begin{array}{c}\text { Millions } \\
\text { of tons }\end{array}$ & $\begin{array}{c}\text { Percent } \\
\text { of total }\end{array}$ & & \\
\hline \multicolumn{8}{|l|}{ Colorado delta: } \\
\hline Boulder Basin...... & 26.9 & 295,000 & 20.7 & 219 & 10.9 & 34.1 & 0.95 \\
\hline Virgin Basin............................. & 28.4 & 142,000 & 10.0 & 123 & 6.1 & 39.8 & 1.25 \\
\hline Temple Bar Area........................ & 8.7 & 59,000 & 4.1 & 54 & 2.7 & 41.8 & 1.40 \\
\hline Gregg Basin............................ & 6.7 & 114,000 & 8.0 & 122 & 6.1 & 49.4 & 2.45 \\
\hline Grand Bay...$\ldots \ldots \ldots \ldots \ldots \ldots \ldots \ldots \ldots \ldots \ldots \ldots$ & 2.7 & 97,000 & 6.8 & 111 & 5.5 & 52.3 & 6.60 \\
\hline Pierce Basin........................... & 2.5 & 144,000 & 10.1 & 214 & 10.6 & 68.2 & 25.0 \\
\hline Lower Granite Gorge.................... & 3.0 & 541,000 & 37.9 & 1,113 & 55.3 & 94.5 & 150.0 \\
\hline Total or mean.......................... & 78.9 & $1,392,000$ & 97.6 & 1,957 & 97.2 & 64.6 & 47.0 \\
\hline $\begin{array}{l}\text { Virgin delta: } \\
\quad \text { Overton Arm } \ldots \ldots \ldots \ldots \ldots \ldots \ldots \ldots \ldots \ldots \ldots\end{array}$ & 21.1 & 34,000 & 2.4 & 57 & 2.8 & 78.2 & 31.0 \\
\hline Total or mean, Lake Mead...... & 100.0 & $1,426,000$ & 100.0 & 2,014 & 100.0 & 64.9 & 44.0 \\
\hline
\end{tabular}


pended sediment settles to the bottom within a few miles of the river entrance, but the high salinity of such interflows can be identified for a considerable distance downstream and thus distinguishes the interflow from the lake water above and below it.

Whenever the density of the inflow is greater than the density of the deeper lake layers, the turbid water plunges beneath the lake surface and travels downlake as an underflow. Water discharged by the Colorado River from October to April is colder, more saline, and more turbid than the deep water in the eastern part of the lake, hence it sinks rapidly beneath the clear water and travels along the submerged Colorado River channel. During this period the division between the turbid river water and the clear lake surface is sharp and distinct and is commonly marked by logs and other debris which collect at the convergence of the opposing surface currents.

Most underflows do not reach the western part of the lake, but at least 12 conspicuous underflows have traveled along the submerged Colorado River channel from the river mouth to Hoover Dam. Of this number, 11 occurred during the first 7 years of reservoir operation (1935-1941) when the lake was from 70 to 120 miles long. The only other major flow of turbid water to reach the dam arrived in the fall of 1947 when the distance between the river mouth and the dam was about 78 miles. Although these extensive currents are comparatively rare, they have transported a tremendous quantity of sediment great distances from the head of the lake. The periods of underflow are marked by a rapid rise in the level of the water-sediment interface behind the dam (fig. 6) whereas the intervals between periods of underflow are marked by a gradual but progressive lowering of the sediment surface due to compaction.

One of the most striking features of the underflows is their low velocity. Mean velocities of 1.0 foot per second are common near the river mouth where the turbid water plunges down the face of the delta front, but by the time these currents reach the flat floor of the Boulder Basin, their velocities are less than 0.25 foot per second and are commonly too low for meas:urement.

In most of Lake Mead, underflows are confined to the submerged channel of the Colorado River and are generally only a few feet thick. Between the entrance of the river in 1948 and the mouth of Iceberg Canyon (a distance of about 14 miles), abundant mixing of the muddy inflow and the lake water occurred several tens of feet above the reservoir bottom, but west of Iceberg Canyon the underflow of turbid water was confined to the very deepest part of the reservoir. In late November 1948, an underflow of muddy water extended into the eastern part of the Virgin Basin. Observations of this current showed a very sharp interface between the muddy flow at the bottom of the lake and the clear water above. The underflow west of Iceberg Canyon was about 3 feet thick and its density ranged from approximately 1.001 at the top to 1.20 at the bottom.

It has been estimated that approximately 50 percent of the total weight of sediment accumulated in the Colorado delta is contained in the fine-grained bottomset beds, and practically all of this material has been transported by turbidity currents developed at the mouth of the Colorado River. Most of the sediment in Boulder Basin has been transported at least 70 miles before finally coming to rest.

The Colorado delta deposits have a minimum thickness of 45 feet in the Temple Bar area about 40 miles above Hoover Dam. The progressively increasing thickness east of this point is normal for a sedimentladen stream entering quiet water. The increasing thickness to the west may be attributed to Hoover Dam, which has arrested the infrequent but farthest traveling turbidity currents and caused deposition of their suspended loads. In open water, some of these currents might have continued for tens or even hundreds of miles, and the total thickness of deposition would decrease progressively from the front of the delta near the point of entrance of the inflowing water.

The suspended particles transported by the Colorado River turbidity currents consist of 67 percent clay, 32 percent silt, and less than 1 percent sand. The coarsest particles are generally deposited near the river mouth and the finest particles at the greatest distance from the source. The sediment may not settle as discrete particles, but as flocculated masses that are 2 to 20 times larger than the individual grains. Studies of suspended sediment in the Lake Mead underflows (Sherman, 1953) and in the Colorado River (Grover and Howard, 1938) show that the material also travels in a flocculated state.

Most of the Virgin River turbidity currents have extended only a short distance into Lake Mead, but observations at Lower Narrows indicate that some underflows of turbid water have traveled through most, if not all, of the inundated Virgin River channel. Records obtained several times each year since January 1938 show that suspended sediment has appeared periodically in the submerged channel between 1938 and 1947. Suspended sediment was observed in the channel at Lower Narrows in April 1948 but by January 1949 it had disappeared. The suspended sediment at Lower Narrows commonly appears prior to the period of Colorado River overflows, and the Virgin River is evidently its source.

\section{Sedimentation in Relation to Reservoir Utilization,} by H. R. Gould

This section forecasts the pattern of sediment accumulation in Lake Mead after evaluating the sedimentstorage capacity of the reservoir and the compaction of the sediment.

The difference between the sediment-storage capacity of Lake Mead and its water-storage capacity is equal to the volume between the level surface at the elevation of the spillway crest and the sloping sediment surface that will extend upstream from the dam when the reservoir becomes filled with sediment. If we assume that the ultimate slope of the topset beds will be at least as great as the slope in 1948 (roughly 1.2 feet per mile), the topset beds when the reservoir is completely filled will intersect the old Colorado River profile about 13.5 miles upstream from the original head of the reservoir and will rise about 160 feet higher than the permanent spillway crest. The sediment-storage capacity above the permanent spillway level is estimated to be about 
6, 900,000 acre-feet, and the total sediment-storage capacity is therefore $35,700,000$ acre-feet.

Sediment compaction has an extremely important bearing on the rate of depletion of water-storage volume and on the life expectancy of the reservoir. The sediment accumulated in Lake Mead consists of two major types of material; namely, the sand of the topset and foreset beds, and the silt and clay of the bottomset beds. The compaction of sand is probably insignificant and can be neglected. The potential compaction of silt and clay, however, is large.

The degree to which silt and clay sediments are compacted is related primarily to their depth of burial and to the size, shape, and sorting of their constituent particles. In order to obtain an average empirical relation between these various factors, the depth and water-content data of all cores from the bottomset beds of both the Colorado and Virgin deltas were plotted, and a best-fit visual curve was drawn which indicated an approximately linear relation between decrease in water content and depth of burial of the bottomset beds throughout a depth interval of 95 feet. By the use of Hedberg's (1936) porosity data for finegrained sediments, it is possible to extend the watercontent curve obtained from the Lake Mead cores to considerably greater depths.

The gates through which water can be discharged from the reservoir are at three levels. The uppermost of these are the spillways with their permanent crest at 1,205 feet elevation. The gates at the two lower levels are situated in the four intake towers immediately uplake from Hoover Dam. The sills of the upper gates are at an elevation of 1, 045 feet, 310 feet above the 1948 sediment surface and 415 feet above the original floor of the reservoir. The sills of the lower gates are at elevation 895 feet, 160 feet above the 1948 sediment surface and 265 feet above the original lake bottom at the intake towers. These are the outlets through which water for generating power and for downstream users is normally discharged.

All water stored below the 895 -foot level is, of course, in dead storage. When water was first impounded behind Hoover Dam, the dead storage space measured 3,223,000 acre-feet, but by January 1949 it had been reduced by the accumulation of sediment to $2,620,000$ acre-feet, or by 18.7 percent. Whenever the dead storage space becomes completely filled with sediment it will be necessary either to discharge great quantities of sediment downstream or to close the lower gates and allow them to become covered. Loss of the dead storage space will thus mark the first critical stage of reservoir filling. Similarly, the filling of the reservoir to the sills of the upper gates in the intake towers and to the permanent spillway crest will denote, respectively, the second and third critical stages.

A total of about 2,000 million tons of sediment (dry weight) has been deposited in Lake Mead during the 14year period 1935 to 1948 . This quantity is taken as a convenient unit of measurement for discussion of the future accumulation of sediment in Lake Mead. This material consists of approximately 45 percent sand and 55 percent silt and clay. The total load of sand, therefore, is 900 million tons, and the total load of silt and clay is 1, 100 million tons. For the few cen- turies under discussion in the following paragraphs, it is assumed that the size distribution will be similar to that in the 2,000-million ton sample accumulated prior to the 1948 survey.

Using a mean specific weight of 93.8 pounds per cubic foot for sand, the total sediment-storage capacity $(35,700,000$ acre-feet) has been reduced 441,000 acrefeet by the sand in the first 2,000 million tons of sediment brought into the reservoir. Since it is assumed that sand will experience no further compaction, the sand in each 2,000-million ton unit will reduce the total sediment-storage capacity by an equivalent amount. The rate of sediment-storage depletion resulting from the accumulation of silt and clay is not constant, but will become progressively less because of increased compaction during the filling of the reservoir.

Based on curves of sediment compaction it is calculated that when Lake Mead reaches its sediment-storage capacity of $35,700,000$ acre-feet, it will contain 74,700 million tons of sediment-37 times as much as in 1948with a mean specific weight of 96.1 pounds jer cubic foot, 48 percent greater than the computed mean in 1948. The sand of the topset and foreset beds will weigh 33,600 million tons, with specific weight of 93.8 pounds. The silt and clay will have a mean specific weight of 98.0 pounds per cubic foot, and a total weight of 41,100 million tons.

The usefulness of the reservoir will not be materially impaired until its water-storage capacity at the level of the permanent spillway crest is reduced to about $13,000,000$ acre-feet, the average annual flow into Lake Mead from 1935 to 1948 . This will occur when the sediment accumulation becomes slightly more than 18 times as great as the amount brought into the lake between 1935 and 1948 . At that time the topset, foreset, and underlying bottomset beds will fill all the reservoir east of Virgin Basin and extend into that basin. The bottomset beds at the dam will reach almost to the level of the upper outlet gates. The water-storage capacity (not including ground-water storage) will be about $13,000,000$ acre-feet below the permanent spillway crest, comprising about $4,500,000$ acre-feet in Boulder Basin, 500, 000 in Boulder Canyon, 5, 000, 000 in Virgin Basin, and 3,000,000 acre-feet in Overton Arm. The total water storage can be increased to about $14,900,000$ acre-feet by raising the spillway gates.

The sediment level at the dam will reach the elevation of the lower outlet gates when the total accumulation becomes about seven times as great as the amount brought into the lake from 1935 to 1948 . At that time the reservoir east of Gregg Basin will be filled with sediment, but abundant storage space will still be available in the western part of the reservoir. The water-storage capacity below the permanent spillway crest will be about $22,000,000$ acre-feet, comprising $6,300,000$ acre-feet in Boulder Basin, 800,000 in Boulder Canyon, 8, 000, 000 in Virgin Basin, 3, 300, 000 in Overton Arm, 2,000,000 in the Temple Bar area, 300,000 in Virgin Canyon, and 1,300,000 acre-feet in Gregg Basin. By raising the spillway gates, the total storage can be increased to about $24,100,000$ acrefeet.

These predictions are based on certain assumptions, of which an important one concerns reservoir operations. It is assumed that the average operating level 
will be at spillway level 35 feet higher than at present, and on that assumption it is predicted that approximately 20 percent of the total sediment load will be deposited above the level of the permanent spillway crest. Lower average operating levels will reduce the proportion of sediment deposited in the upper part of the reservoir, extend the delta front downlake, reduce the area available for deposition of silt and clay, and result in a more rapid rise of the sediment level at the dam.

In the foregoing discussion of the various stages of reservoir filling it has been assumed that all the sediment transported into Lake Mead will be deposited in the lake and that none will be discharged through the outlet gates or spillway tunnels of Hoover Dam. If the outlet gates are used for discharging sediment through the dam, however, it is likely that the reservoir will never become entirely filled with sediment but will eventually reach a terminal stage when all the sediment transported into the lake will be discharged through the outlet gates and spillway tunnels of Hoover Dam.

\section{LIFE OF THE RESERVOIR}

By H. E. Thomas, H. R. Gould, and W. B. Langbein

The quantities of sediment that may eventually be deposited in Lake Mead-about 75,000 million tons when the reservoir is completely filled, or 37,000 million tons at the half-way point, as calculated by Gould-are essential items in the computation of the life of the reservoir. The life, or the half-life, of the reservoir in years depends also upon the average annual rate of sediment accumulation. The life of the reservoir is forecast first on the assumption that the average rate of accumulation in the 14-year period 1935-48 will continue in the future, and then on the basis of analyses of other hydrologic data for the purpose of evaluating the "normal" rate of accumulation.

\section{Projection of Observed Rates of Sediment Accumulation}

\section{Some estimates of the probable life of Lake Mead} have been based on projection of the observed rates of sediment accumulation at Hoover Dam. As shown by figure 6 the top of the sediment rose 100 feet in the first 3 years of operation of the dam, and then rose another 40 feet by the fall of 1941 , less than 7 years after water was first impounded. This rapid rise of the sediment level--to a position about halfway between the original river bed and the lower gates at the intake towers-could lead to very pessimistic estimates as to the life of the reservoir. However, the rapid rise is readily explained by the shape of the reservoir: the volume in the lowest 100 -foot layer of the reservoir (below elevation 720 feet) constitutes less than 0.5 percent of the reservoir capacity. Records since 1941, too, show that sediment compaction is a very important factor at the dam, for by January 1950 the sediment level at the intake towers was 38 feet lower than it had been in 1941. Projections of the observed rate of sediment accumulation into the future necessarily lead to erroneous estimates of the life of the reservoir, if they neglect the factor of compaction.
Other estimates of the life of Lake Mead have been based upon projection of the ratio of sediment volume to the water-storage capacity of the reservoir. In the 1948-49 survey it was determined that the volume occupied by sediment was $1,426,000$ acre-feet, and thus the average annual rate of accumulation in the 14 -year period was 102, 000 acre-feet. By projection of this rate of accumulation, the time required for a sediment volume equivalent to the original water-storage capacity of Lake Mead would be 280 years.

The maximum life of the reservoir will be considerably greater than this, however, because 1) the sediment-storage capacity is greater than the waterstorage capacity of the lake, and 2) the current average specific weight of the sediment will be increased by compaction. From consideration of the principles of stream gradation and the history of delta building in Lake Mead to date it has been concluded (p. 21) that the sediment-storage capacity of the reservoir is about 25 percent greater than the water-storage capacity. From analysis of core samples and other data, it has been estimated ( $p .22$ ) that the average specific weight of the sediment when the reservoir is completely filled will be nearly 50 percent greater than the average of the deposit in 1948. The 2,000 million tons of sediment deposited in the 14-year period (1935-48) constitutes only 2.7 percent of the calculated ultimate storage capacity of nearly 75,000 million tons. By projection of this rate of accumulation, the probable maximum life of the reservoir is computed to be about 520 years. The time required to reach the half-way point, when accumulation of 37,000 million tons of sediment will have reduced the water-storage capacity at the permanent spillway crest to $13,000,000$ acre-feet, would be about 260 years.

\section{"Normal" Rate of Sediment Accumulation}

In using the record for a 14-year period to forecast events 5 centuries in the future, we are using an exceedingly short base and projecting it for nearly 40 times its length. Any inaccuracies in that base are similarly magnified in the forecasts. Thus, if on the average it takes only 12 years for streams to carry the 2,000 million tons that reached Lake Mead in the 14year period, the probable life of the reservoir would be shortened by 75 years. The records at Grand Canyon show that there is sufficient variability in sediment load to justify a great range in forecasts as to the probable life of the reservoir. In the single year 1927 the suspended load of 480 million tons was nearly one-fourth of the total carried in the 14-year base period; and in the 8 years $1926-33$ the river carried 2, 000 million tons of sediment past the Grand Canyon station--as much as was carried in the 14-year period 1935-48.

Hydrologists are generally agreed that the period 1935-48 was not a normal period, for the average runoff was appreciably less than averages for longer terms, and the sediment load was also less than the average for the entire period of record. The problem is complicated by the fact that the sediment-runoff relation since 1941 has been notably different from that recorded in earlier years. 
The volumetric survey of 1948 provides only one point of correlation between runoff and sediment: that 2, 000 million tons of sediment was carried into the reservoir by 176 million acre-feet of Colorado River water, plus the unmeasured flow of other tributaries. Any detailed analysis of the rate of sediment transportation in relation to stream discharge depends on records of suspended load, especially the record for the Colorado River at Grand Canyon.

The record of sediment at Grand Canyon, beginning in 1926, provides information as to the suspended load and contemporaneous runoff for nearly a quarter of a century. Records of river discharge cover a longer period, and climatic fluctuations are inferred for a still longer period, but the sediment-runoff relationships in these extended periods must be extrapolated from the relatively short sediment-gaging records.

The average annual load of suspended sediment passing the Grand Canyon gaging station in the 23 -year period 1926-48 was 175 million tons, or about 23 percent greater than the mean annual load (142 million tons) during the 14-year period 1935-48. The mean annual runoff in the 23 -year period was 12.8 million acrefeet, or 2 percent greater than the average for the period 1935-48. If the high suspended load recorded at Yuma in the years 1911-25 is representative of Upper Basin, it appears that the rate of sediment transport into the Lake Mead area during the 38-year interval 1911-48 may possibly be as much as 60 percent above the $1935-48$ average.

Schulman's (1945) tree-ring investigations in Upper Basin provide a basis for estimating the average rate of runoff of the Colorado River during the past several hundred years. Extrapolation of his results, together with available runoff records, suggests that the average annual virgin streamflow at the Grand Canyon station during the 658-year period 1288-1945 has been about $15,800,000$ acre-feet, slightly less than the estimated virgin flow in the period 1897-1948. However, this long-term average is about 7 percent greater than the estimated actual flow in the 52 years, 23 percent greater than the measured flow in the period 1926-48, and 27 percent greater than the average discharge in the 14-year period 1935-48. The depletions caused by water development, currently about 2, 200, 000 acrefeet a year, will doubtless insure that the average flow at Grand Canyon in the future will be less than the average as indicated by tree-ring records. With no increase in the amount of upstream diversions, this long-term future average should be about 13,600,000 acre-feet, or 8 percent greater than the average in the 14 -year period 1935-48.

In four years since 1926 the annual runoff at Grand Canyon has been close to the projected long-term mean of $13,600,000$ acre-feet: In 1930,1944, 1947, and 1948 the runoff ranged from $13,400,000$ to $13,900,000$ acre-feet. These four years demonstrate the striking variation in sediment transport that is characteristic of the records to data. The measured sediment load was more than 235 million tons in 1930 , but less than 98 million tons in 1944 . In both 1947 and 1948 the load was close to the 142 million-ton average for the 14 year period 1935-48. Similar inconsistencies are apparent throughout the record, including years of high as well as low runoff. Thus in 1950 less sediment was carried in 11, 200,000 acre-feet of water than was transported by $6,700,000$ acre-feet in 1931; and $17,300,000$ acre-feet of water carried 389 million tons of sediment in 1927, but only 230 million in 1942 .

As shown by figure 5 the sediment-runoff relation in the years 1942 to 1950 is as consistent as for earlier years of record, and the curve showing that relation is approximately parallel to that drawn on the basis of records for the years 1926 to 1940 . However, in each of the later nine years the annual sediment load has been 50 to 100 million tons less than would be expected on the basis of the curve established by data for years prior to 1941 .

Neither the annual runoff nor the seasonal distribution of runoff since 1941 has been perceptibly different from that in earlier years, and thus neither offers an explanation for the change in sediment-runoff relationship that year. Since that year introduced a new and different relation that has persisted for at least 9 years, the factor or factors causing the change must have been effective for a similarly long period. It is believed that a possible explanation may lie in longterm trends in regional precipitation. The southwestern United States since 1941 has recorded a drought which is recognized as one of the eight most severe droughts in 600 years. Lake Mead is within this drought area, but the principal sources of its water supply are far to the north, in a region where precipitation has generally been about normal. The drought-affected area includes most of the sediment-producing area of the Colorado River basin: the basins of the Virgin, Little Colorado, San Juan, and Dirty Devil Rivers, and smaller tributaries that enter the Colorado below the mouth of the Green River. The change in sediment-runoff relation since 1941 may well be a product of drought; reduced streamflows in sediment-producing tributaries, and corresponding reduction in contribution of sediment from them; normal streamflow from the high headwater areas in Colorado, Wyoming, and northern Utah.

The life of Lake Mead will be prolonged if some of the sediment is permitted to pass through the reservoir and dam and continue downstream. At the present time, of course, there is no possibility of passing sediment through the intake towers and there is little likelihood of doing so in the near future, because the water is habitually clear at the lower gates of the intake towers. At some time in the future it is inevitable that the sediment surface will approach that level, and it will then become a question of operational policy whether to cease using the lowest reservoir outlets or to draw sediment-laden water through them. If passage of sediment-laden water through the lower gates is accepted as normal procedure, the outflow of sediment will be nil for several decades, while the sediment surface rises toward the 895 -foot level. Then one may expect sediment outflow, occasionally at first as a result of exceptional turbidity currents, then more frequently and with greater volumes of sediment as the sediment surface in Boulder Basin continues to rise.

From the foregoing discussion, the following conclusions are believed to be warranted as to the future rates of sediment accumulation Lake Mead:

1. The average annual rate of suspended-load transport at Grand Canyon in the 14-year period 1935-48 is 142 million tons, and this rate is well confirmed by the calculated total of sediment accumulated in Lake Mead 


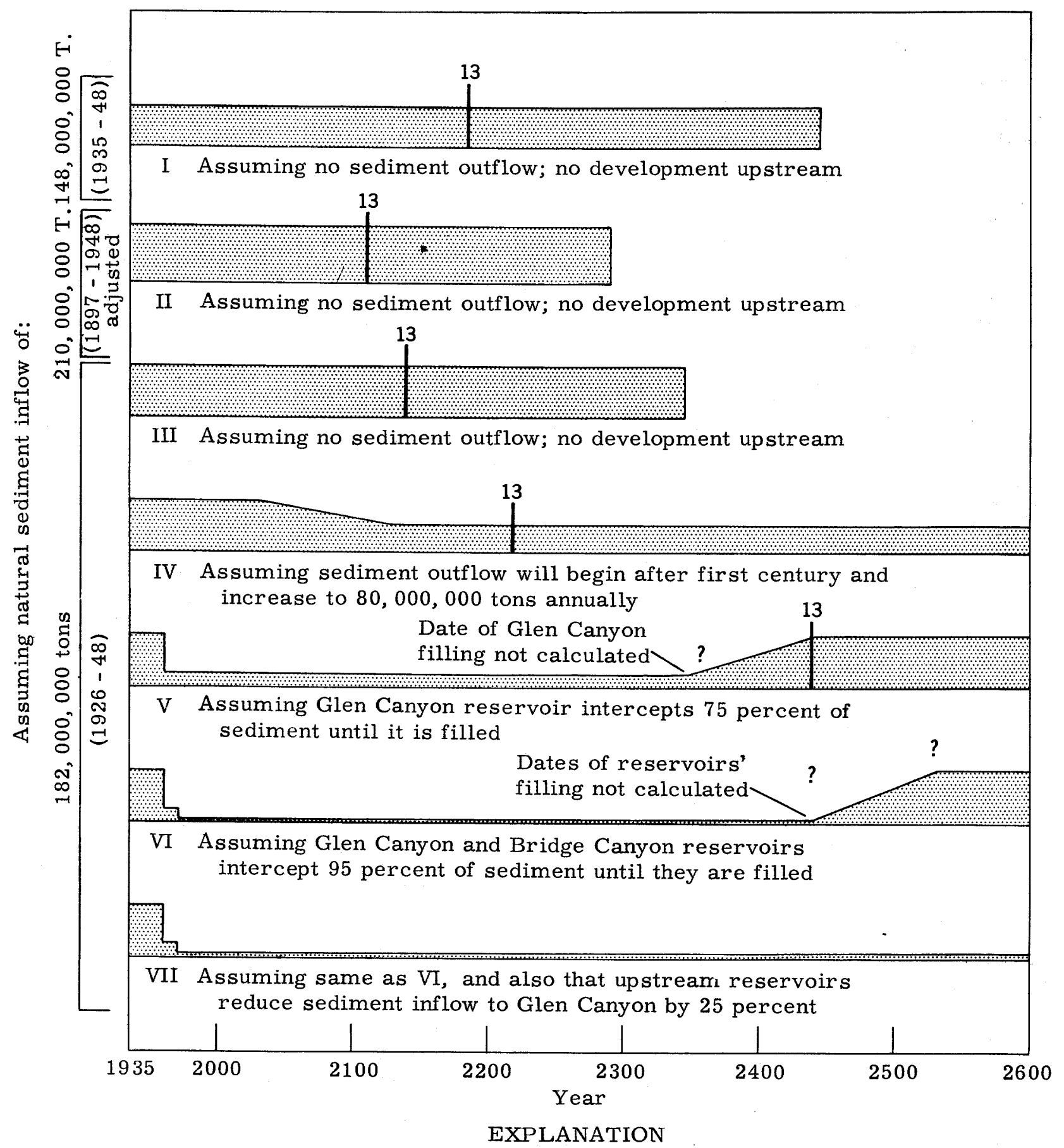

Width of bar is proportional to net rate of sediment accumulation

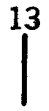

Indicates time when water - storage capacity is reduced to $13,000,000$ acre - feet 
during the period. However, the quantities calculated by both methods are probably 3 to 5 percent less than the total sediment deposited in the lake in the 14-year period. The error in suspended load measurements results chiefly from the omission of unmeasured loads of the Virgin River and other minor tributaries to the lake, whereas the error in measurements of the quantity of sediment accumulated in the lake results from the omission of unmeasured amounts of sediment deposited during the 1935 and 1948 surveys. The uppermost graph of figure 9 is based on the assumption that sediment accumulation will continue at the rate of approximately 148 million tons a year, or 4 percent more than the average annual suspended load at Grand Canyon during 1935-48.

2. The average annual rate of suspended-load transport at Grand Canyon in the last 7 years of this 14 year period was only 104 million tons, but this reduced rate is attributed to exceptional climatic variations within the basin and is not considered to be indicative of future trends. Inclusion of the data for these 7 years has of course lowered the average annual rate in the 14-year period.

3 . The average annual suspended-load transport at Grand Canyon in the 23-year period 1926-48 is 175 million tons, and if a 4-percent allowance is made for unmeasured contributions to the river above Black Canyon (as in 1935-48), the estimated average rate of sediment inflow to the Lake Mead area would be increased to $182,000,000$ acre-feet a year. Most of the graphs of figure 9 are based on a projection of this rate.

4. Correlation of sediment records at Grand Canyon and at Yuma is considered to be too weak to justify conclusions as to rates in years prior to 1926 .

5. The average annual runoff in the 23 -year period 1926-48 was only 2 percent greater than in the 14 -year period 1935-48. There is evidence from tree-ring studies that the long-term average virgin flow of the Colorado River at Grand Canyon is about 15, 800, 000 acre-feet annually, which is slightly less than the average obtained from extended records of streamflow in 1897-1948, corrected for stream depletions. With current depletions, however, the estimated long-term average at Grand Canyon is about 13.6 million acrefeet a year. The 1926-40 curve on figure 5 offers a possible sediment-runoff relation, based on 15 years of record: with annual runoff of 13.6 million acre-feet the annual sediment load would be about 200 million tons. The basis for this estimate is weak, because of the great uncertainty as to the sediment-runoff relation.

6. The construction of Glen Canyon reservoir will intercept more than 75 percent of the sediment moving toward Lake Mead, and together with Bridge Canyon reservoir will intercept about 95 percent of it, until the two reservoirs start spilling sediment. Upstream development and use of water may reduce the sediment inflow to these two reservoirs by about 25 percent.

7. After the sediment level at Hoover Dam has risen to the level of the lower outlet gates, silt and clay can be passed through the turbines until the rate of sediment outflow approaches half the rate of sediment inflow.
The graphs of figure 9 demonstrate the variation in estimates based on various assumptions as to the future. More significant, they show that the benefits of Lake Mead will continue for many centuries and that the usefulness of the reservoir will not be seriously impaired.

\section{PROBLEMS FOR FUTURE STUDY}

The Lake Mead survey has provided answers to many perplexing questions, but equally important, it has raised many new questions and serves to focus attention upon problems that require further study. Many of the conclusions throughout the technical report are necessarily hedged because of the incompleteness of our knowledge. This is particularly noticeable relative to the life of the reservoir, which is necessarily speculative because it is concerned with future centuries, but which must be satisfied with wide limits because of uncertainty both as to observed phenomena and basic principles of sedimentation. The Lake Mead survey serves as an introduction both to a discussion of problems related to reservoirs in general by Thomas Maddock, Jr., and to discussions of the broad hydrologic and geologic problems of the Colorado River basin by C. B. Hunt and H. E. Thomas.

\section{LITERATURE CITED}

Anderson, E. R., and Pritchard, D. W., 1951, Physical limnology of Lake Mead: Navy Electronics Lab., Rept. 258, 152 p.

Bell, H. S., 1942a, Density currents as agents for transporting sediment: Jour. Geology, v. 50, p. 514.

$1942 \mathrm{~b}$, Stratified flow in reservoirs and its use in the prevention of silting: U. S. Dept. Agriculture Misc. Pub. 491, 46 p.

Gould, H. R., 1951, Some quantitative aspects of Lake Mead turbidity currents: Soc. Econ. Paleontologists and Minerologist, Special Pub. 2, p. 34-52.

Grover, N. C., and Howard, C. S., 1938, The passage of turbid water through Lake Mead: Am. Soc. Civ. Eng. Trans., v. 103, p. 720-732.

Hedberg, H. D., 1936, Gravitational compaction of clays and shales: Am. Jour. Sci., v. 31, p. 241 287.

Longwell, C. R., 1936, Geology of the Boulder Reservoir floor; Geol. Soc. America Bull., v. 47, p. 1393-1476.

Schulman, Edmund, 1945, Tree-ring hydrology of the Colorado River basin: Univ. Ariz. Bull., v. 16, no. 4.

Sherman, Irving, 1951, A rapid substitute for textural analysis: Jour. Sed. Petrology, v. 21, p. 173-177.

1953, Flocculent structure of sediment suspended in Lake Mead: Am. Geophys. Union Trans., v. 34, p. 394-406. 
Sykes, Godfrey, 1937, The Colorado delta: Am. Geog. Soc., Special Pub. 19, p. 132-133.

Terzaghi, Karl, 1925, Principles of soil mechanics, elastic behavior of sand and clay: Eng. NewsRecord, v. 95, p. 989-990.

U. S. Dept. Agriculture, Soil Conservation Service, 1935, Topographic maps of Lake Mead area: 52 sheets at scale $1: 12,000$

U. S. Dept. Interior, Bureau of Reclamation, 1941, Lake Mead density currents investigations 1937-40, v. 1 and 2,453 p.
U. S. Dept. Interior, Bureau of Reclamation, 1947, Lake Mead density currents investigations 1941-46, v. 3, p. 454-904.

1949, Report of river control work and investigations in 1948 and 1949: Office of River Control, Boulder City, Nev., p. 53-124.

1953, Report of river control work and investigations in 1950 and 1951: Office of River Control, Boulder City, Nev., p. 59-94. 



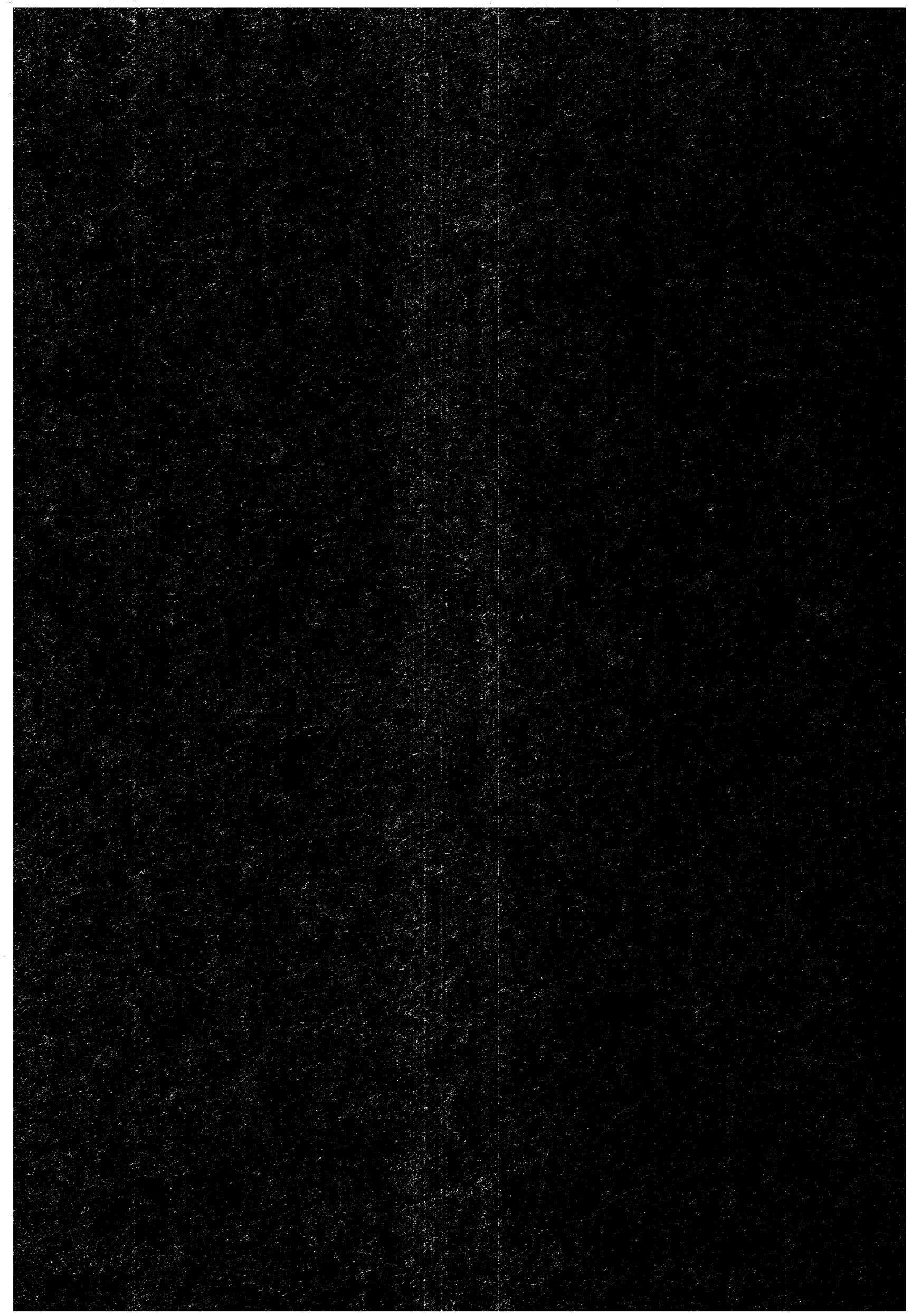




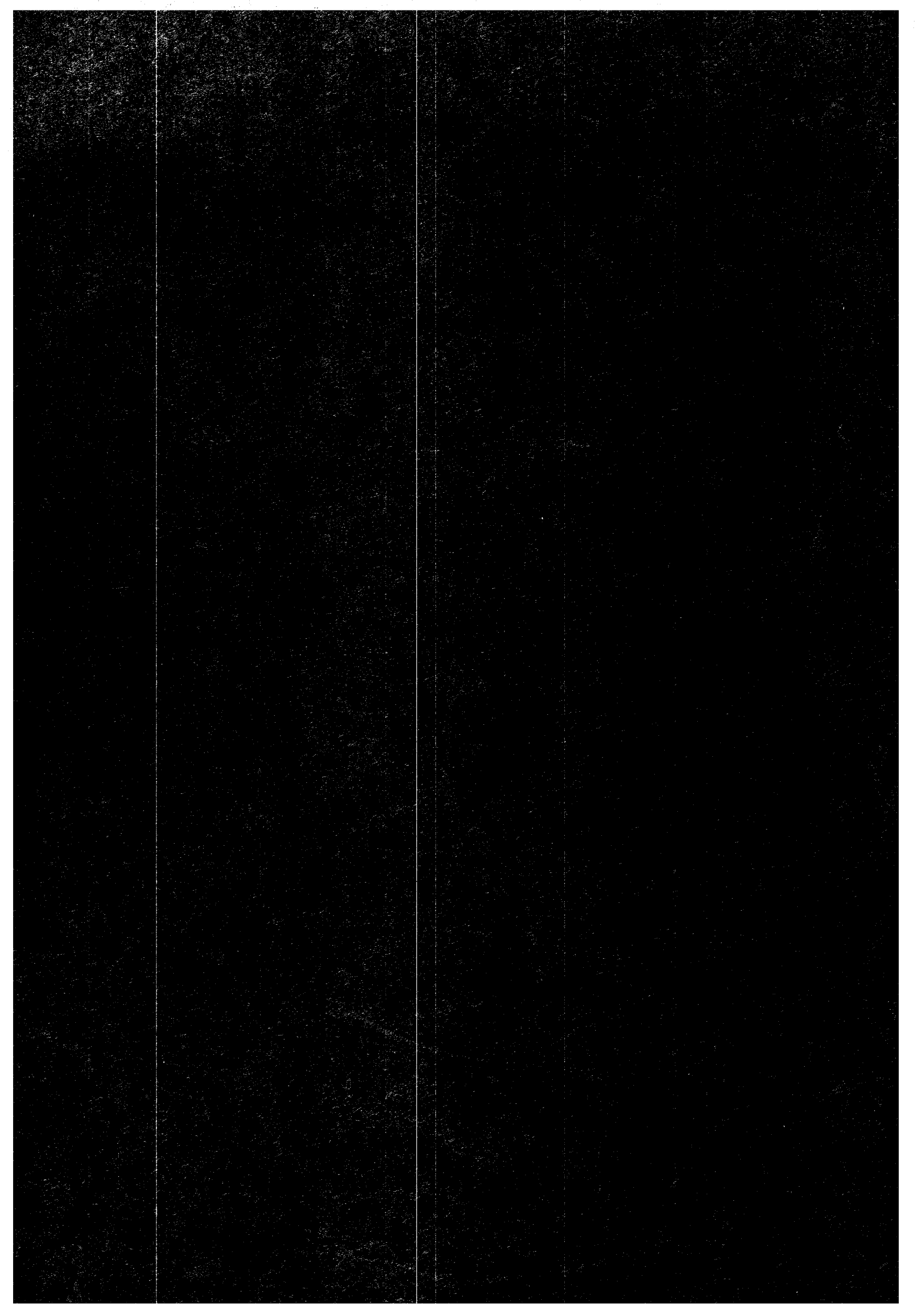

